San Jose State University

SJSU ScholarWorks

Master's Theses

Master's Theses and Graduate Research

Fall 2015

\title{
Lithologic controls on knickpoint formation in Sierra Nevada bedrock channels
}

Brittany Danielle Johnson

San Jose State University

Follow this and additional works at: https://scholarworks.sjsu.edu/etd_theses

\section{Recommended Citation}

Johnson, Brittany Danielle, "Lithologic controls on knickpoint formation in Sierra Nevada bedrock channels" (2015). Master's Theses. 4641.

DOI: https://doi.org/10.31979/etd.36yj-4qzk

https://scholarworks.sjsu.edu/etd_theses/4641

This Thesis is brought to you for free and open access by the Master's Theses and Graduate Research at SJSU ScholarWorks. It has been accepted for inclusion in Master's Theses by an authorized administrator of SJSU ScholarWorks. For more information, please contact scholarworks@sjsu.edu. 
LITHOLOGIC CONTROLS ON KNICKPOINT FORMATION IN SIERRA NEVADA BEDROCK CHANNELS

\author{
A Thesis \\ Presented to \\ The Faculty of the Department of Geology \\ San José State University \\ In Partial Fulfillment \\ of the Requirements for the Degree \\ Master of Science
}

by

Brittany Danielle Johnson

December 2015 
(C) 2015

Brittany Danielle Johnson

ALL RIGHTS RESERVED 
The Designated Thesis Committee Approves the Thesis Titled

\section{LITHOLOGIC CONTROLS ON KNICKPOINT FORMATION IN SIERRA NEVADA BEDROCK CHANNELS}

by

Brittany Danielle Johnson

APPROVED FOR THE DEPARTMENT OF GEOLOGY

SAN JOSÉ STATE UNIVERSITY

August 2014

Dr. Emmanuel Gabet

Dr. Paula Messina

Dr. Robert Miller
Department of Geology

Department of Geology

Department of Geology 


\section{ABSTRACT \\ LITHOLOGIC CONTROLS ON KNICKPOINT FORMATION IN SIERRA NEVADA BEDROCK CHANNELS}

by Brittany Danielle Johnson

In the Sierra Nevada Mountains, the distribution of knickpoints in bedrock channels is often used as evidence to argue that the mountain range has been recently uplifted. The assumption that bedrock channel knickpoints are transient features responding to a recent pulse of uplift contributes to the ongoing debate about the range's geomorphic and tectonic evolution. Determining how knickpoints form in heterogeneous granitic landscapes remains fundamental in understanding the lithologic, tectonic, and climatic controls on bedrock incision. Defining the controls on knickpoint formation may limit how knickpoints are used to infer the tectonic history of the Sierra Nevada. In this study, tributaries of the North Fork Feather and Merced Rivers are examined because they are underlain by a variety of rock types, thereby providing an opportunity to investigate the relationship between lithologic diversity and knickpoint formation. In these tributaries, bedrock above knickpoints is often finer grained with a higher percentage of quartz than bedrock below the knickpoint. The differences in bedrock grain size and quartz content are found to be statistically significant. This study argues that variations in rock hardness predispose lithologically heterogeneous bedrock channels to express transitions in a channel's resistance to erosion as knickpoints. Thus, knickpoints in Sierra Nevada bedrock channels may have formed by differential erosion rather than uplift-driven incision, and using Sierra Nevada bedrock channel knickpoints as a tool to interpret tectonic activity is arguably inappropriate. 


\section{ACKNOWLEDGEMENTS}

Thank you to my family and friends that operated as team of intelligent field assistants, working tirelessly over weekends and holidays in often harsh field conditions: Derek Selander, James Johnson, Jean Johnson, Danika Johnson, and Ghazal Mowlavi. Thank you Derek Selander and James Johnson for your countless discussions and your careful edits on the first drafts of this manuscript. This project could not have been completed without your constant help and support. Thank you to my committee members, Dr. Paula Messina and Dr. Robert Miller, for their invaluable incite and meticulous edits that helped improve this manuscript. A special thanks to my thesis advisor, Dr. Emmanuel Gabet for directing me to this project, his constant guidance and supervision, for sparking my interest in the subject of fluvial geomorphology and providing me a platform that will allow me to continue my education in the subject. 


\section{TABLE OF CONTENTS}

INTRODUCTION

METHODS

Field Site

Longitudinal Profiles............................................................................ 14

Field Analysis...................................................................................... 14

Mineral and Textural Analysis................................................................. 15

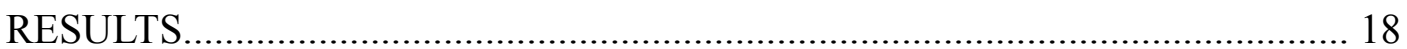

Longitudinal Profile Analysis..................................................................... 18

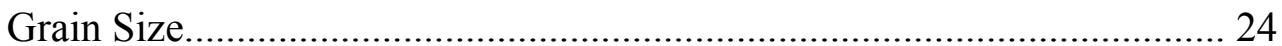

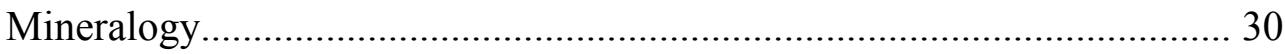

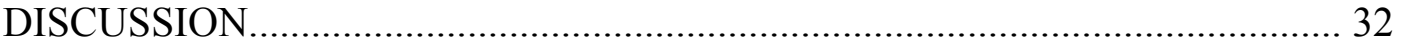

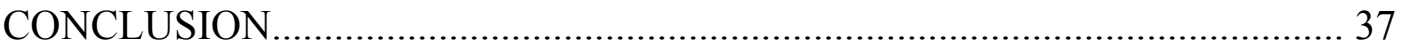

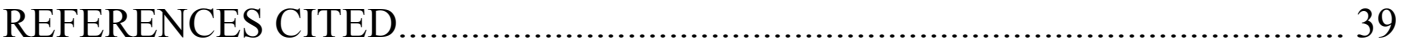

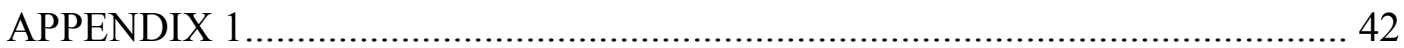

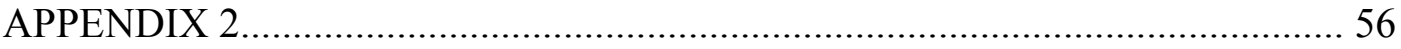




\section{LIST OF FIGURES}

1. Map showing main rivers on the western slope of the central and northern Sierra Nevada.

2. Topography, tributaries, and bedrock sample locations along the North Fork Feather River.

3. Map of the Merced River flowing through Yosemite Valley.

4. Longitudinal profiles of the Merced River tributaries compared to their underlying lithology

5. Longitudinal profiles of the Feather River tributaries are compared to their underlying lithology.....

6. The boxplots organize the data by bedrock samples above and below knickpoints, juxtaposing the rock grain size and mineralogy data at each

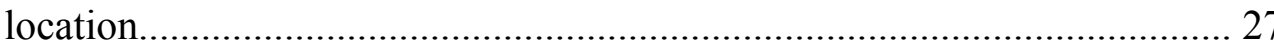

7. Quartz content and average grain size of bedrock above and below knickpoints. 


\section{LIST OF TABLES}

1. Mineralogy and grain size results.......................................................... 25

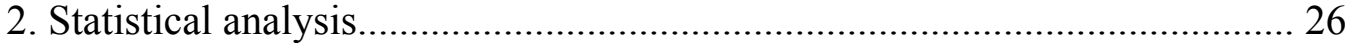




\section{INTRODUCTION}

Bedrock channel profiles are often used for interpreting the tectonic and geomorphic history of landscapes (e.g., Matthes, 1930; Burbank et al., 1996; Howard, 1998; Wakabayashi and Sawyer, 2001; Clark et al., 2005; Crosby and Whipple, 2005; Figueroa and Knott, 2010; Pederson and Tressler, 2010; Walsh et al., 2011; Allen et al., 2013; Wakabayashi, 2013). However, in the Sierra Nevada Range, the influence that lithologic variation has on channel slope is largely unexplored. The ambiguity surrounding how lithologic heterogeneity affects channel slope has allowed for the evolution of the mountain range to be open to a variety of interpretations (e.g., Clark et

al., 2005; Figueroa and Knott, 2010; Wakabayashi, 2013; Gabet, 2014). Some have found geomorphic evidence supporting an old, slowly eroding landscape (Gabet, 2014), while others have found evidence suggesting that the Sierra Nevada has been recently uplifted and rapidly incised (e.g., Matthes, 1930; Clark et al., 2005; Figueroa and Knott, 2010; Wakabayashi, 2013). The debate over the geologic history of the Sierra Nevada has spurred a re-analysis of the geomorphic evidence used to interpret tectonic activity (Gabet, 2014). Much of the geomorphic evidence using bedrock channel profiles to infer late Cenozoic uplift and tilt (e.g., Clark et al., 2005; Figueroa and Knott, 2010; Wakabayashi, 2013) is equivocal (Gabet, 2014). Each study analyzing river profiles fails to account for the lithologic variation characteristic of the region. Because bedrock river incision is an important tool used to infer signals of lithologic, tectonic, and climatic variations in landscapes, understanding why and how knickpoints form in heterogeneous bedrock remains crucial to confirming whether knickpoints are suitable tools for 
deciphering the tectonic history of the Sierra Nevada.

Bedrock rivers are defined as channels without a continuous cover of alluvial sediments at low flows (Whipple, 2004). If the transport capacity is greater than the overall sediment supply, a channel may have a thin alluvial cover and still be defined as bedrock (Gilbert, 1877; Howard et al., 1994; Howard, 1998; Stock and Montgomery, 1999; Whipple, 2004). Bedrock river profiles often express changes in lithologic strength, sediment supply, and erosional processes (Allen et al., 2012). At equilibrium, bedrock rivers are thought to have a graded longitudinal profile that is both smooth and concave. An abrupt localized convexity in a river profile, or knickpoint, can be either a transient or stationary feature (Crosby and Whipple, 2006; Pederson and Tressler, 2012). Transient knickpoints migrate up channel networks and signal disequilibrium caused by external forcings such as uplift or climate change (Pederson and Tressler, 2012). Conversely, stationary knickpoints are formed by local equilibrium adjustments, such as discharge increases at tributary junctions or lithologic transitions (Wahrhaftig, 1965; Howard, 1998; Walsh et al., 2011; Allen et al., 2012; Pederson and Tressler, 2012; Migon and Vieira, 2013). For example, when a bedrock channel flows over two rock types, the weaker bedrock can be eroded at a faster rate than the more resistant rock type and a stationary knickpoint will be anchored at the lithological contact, separating the two distinct reaches of lithologically controlled gradients (Pederson and Tressler, 2012).

Knickpoint development and propagation are dependent on bedrock incision rates. According to one hypothesis, rates of bedrock incision are a function of substrate resistance, channel discharge, and slope (Stock and Montgomery, 1999). These variables 
can work in concert, causing interpretations of the drivers that adjust a channel's equilibrium profile to be difficult to discern (Wahrhaftig, 1965; Howard, 1998; Stock and Montgomery, 1999; Allen et al., 2012; Pederson and Tressler, 2012). Although quantifying longitudinal profile form is particularly imprecise in bedrock river systems, in channels underlain by weak bedrock it can be roughly estimated by relating the local channel gradient, $S$, to the upstream drainage area, $A$, using Flint's law:

$S=k_{S} A^{-\theta}$

where $k_{s}$ is the steepness index and $\theta$ is the concavity index (Howard, 1998; Stock and Montgomery, 1999; Allen et al., 2012; Pederson and Tressler, 2012). The concavity index depends on the erosional resistance of the bedrock, and the steepness index is dependent on both the bedrock resistance and uplift rate (Duvall et al., 2004). While Flint's law can roughly quantify channel gradients in bedrock rivers underlain by weak rock, it does not have the sophistication to include all the variables affecting channel slope in more resistant rock types (Stock and Montgomery, 1999; Duvall et al., 2004; Pederson and Tressler, 2012).

According to another hypothesis, the sediment grain size distribution, sediment supply, and tensile strength of bedrock channels are influential controls on rates of incision caused by abrasion (Sklar and Dietrich, 1998). In laboratory experiments, rocks with different tensile strengths, such as quartzite, granite, and sandstone, can have abrasion-driven incision rates that differ by several orders of magnitude. Additionally, 
gravel that is stronger than the bedrock that it is abrading can incise at rates up to three times faster than gravel that has a tensile strength less than or equal to its underlying bedrock, which further obscures the interpretations of the drivers of bedrock incision. The variable incision rates caused by non-uniform lithology present yet another confounding variable when studying natural bedrock channels.

Field and digital elevation model (DEM) analyses of knickpoints are broadly employed methods used to decipher drivers of local bedrock incision, and are fundamental in deciphering the geomorphic histories of landscapes (e.g., Burbank et al., 1996; Howard, 1998; Crosby and Whipple, 2005; Pederson and Tressler, 2010; Walsh et al., 2011; Allen et al., 2013). For example, in the Annapurna Range, in the central Nepalese Himalaya, 25-m DEMs were used to extract longitudinal profiles to compare profile knickpoints with the underlying geology (Walsh et al., 2011). While no statistically significant relationship between longitudinal profile and lithology was established, analyzing the spatial distribution of those knickpoints helped prove that knickpoints can form in tectonically active landscapes in the absence of active faulting (Walsh et al., 2011). The largest knickpoints occur where landslide dams have been breached, further demonstrating that channel knickpoints are not infallible signal of tectonic activity (Walsh et al., 2011). In the Himalayas near Mohand, India, analyzing channel knickpoints helped identify how channel adjustments become decoupled from changes to drainage area or slope where variations in substrate strength or uplift rates exist (Allen et al., 2013). On the Colorado Plateau, analyzing the spatial distribution of knickpoints and the underlying geology revealed that bedrock channel form is not a 
consequence of tectonic uplift, but a product of lithologic heterogeneity, where rates of incision depend on underlying bed strength (Pederson and Tressler, 2012). Substrate and sediment supply largely influence bedrock channel morphology, and in geologically heterogeneous landscapes, there is a potential for channel slope to become decoupled from tectonics (Allen et al., 2013). Before using knickpoints as a diagnostic of uplift, the relationships between substrate strength, sediment supply, and channel slope must be explicitly defined (e.g., Burbank et al., 1996; Howard, 1998; Pederson and Tressler 2012).

The interplay between lithologic strength, drainage area, total discharge, grain size, bed cover, and particle strength additionally complicates how knickpoints can be used to interpret the driving forces responsible for bedrock channel incision (Sklar and Dietrich, 1998). In Sierra Nevada research, river profiles and their knickpoints are often used to decipher incision rates and interpret tectonic uplift (Matthes, 1930; Wakabayashi and Sawyer, 2001; Clark et al., 2005; Figueroa and Knott, 2010; Wakabayashi, 2013). Matthes (1930) was the first to use river profile knickpoints to infer the tectonic history of Yosemite Valley, a practice still used in modern studies of the Sierra Nevada (Wakabayashi and Sawyer, 2001; Clark et al., 2005; Figueroa and Knott, 2010; Wakabayashi, 2013). Matthes (1930) examined the longitudinal profiles of some Yosemite Valley tributaries and discovered that knickpoints occurred at similar elevations throughout the valley. Matthes (1930) concluded that these knickpoints represented the pre-uplift terrain and that the elevation difference between the paleo-elevation surface and the current channel bottom was the total amount of uplift-driven incision. Matthes' 
and similar studies fundamentally rely on the assumption that bedrock channel knickpoints are transient features migrating upstream in response to uplift (Gabet, 2014). Although the premise of Matthes' (1930) assumption was refuted by Wahrhaftig (1965), it remains ingrained in the geomorphic study of the Sierra Nevada (e.g., Wakabayashi and Sawyer, 2001; Figueroa and Knott, 2010; Wakabayashi, 2013). When a sample of the Sierra Nevada longitudinal profiles were reexamined, the knickpoint elevations did not match the patterns proposed by Matthes (1930), and were found to be randomly distributed, implying that Sierra Nevada knickpoints may not necessarily be transient features responding to uplift (Wahrhaftig, 1965).

In lithologically homogeneous environments, fractures can have a greater influence on patterns of erosion than in lithologically heterogeneous landscapes (CoudeGaussen, 1981, in Lagasquie et al., 2012). Beyond serving as a structural weakness, fractures can act as conduits of preferential flow, allowing water to bypass matrix infiltration by shuttling water faster and deeper into the bedrock to potentially accelerate rates of chemical weathering (Coude-Gaussen, 1981, in Lagasquie et al., 2012). In lithologically heterogeneous landscapes like the Sierra Nevada, the correlation between fracture location and patterns of differential erosion fade, and texture and mineralogy have a greater influence on identifiable patterns of erosion (Godard, 1965, in Lagasquie et al., 2012).

When studying the evolution of landscapes with crystalline bedrock, recognition of the effect that varied texture and mineralogy have on rock strength is fundamental to understanding how local changes in lithology may affect landscape morphology 
(Lagasquie et al., 2012). However, a basic investigation into how landscape form is affected by the bedrock type is excluded in most research on the evolution of the Sierra Nevada's granitic terrain (e.g., Matthes, 1930; Wakabayashi and Sawyer, 2001; Clark et al., 2005; Figueroa and Knott, 2010; Wakabayashi, 2013). In granitic landscapes, knickpoints can occur at lithologic transitions where erosion rates are controlled by the bedrock's mineralogy and texture (Lagasquie et al., 2012; Migon and Vieira, 2013). Granites studied in Scotland (Godard, 1965, in Lagasquie et al., 2012), France (Flageollet, 1977, in Lagasquie et al., 2012), Norway (Puelvast, 1985b, in Lagasquie et al., 2012), and Portugal (Migon and Vieira, 2013) indicate patterns between elevation and the bedrock's mineral content and texture. The granites with higher tensile strengths and resistance to erosion are more frequently found at higher elevations. These resistant granites are consistently more quartz-rich and finer-grained than the less resistant granites (Godard, 1965, in Lagasquie et al., 2012; Migon and Vieira, 2013). The more easily erodible granites that underlie the lower elevations typically have coarser-grain sizes and less quartz (Lagasquie et al., 2012; Migon and Vieira, 2013). In lithologically heterogeneous landscapes, variations in rock hardness cause individual rock units to erode at different rates. In bedrock channels, variation in bedrock erodibility is capable of forming stationary knickpoints at lithologic contacts (Pederson and Tressler, 2012).

The Sierra Nevada's diverse pluton assemblage offers a unique natural laboratory to investigate knickpoint distributions along channels incising through lithologically variable bedrock (Bateman and Wahrhaftig, 1966; Heitanen, 1973; Calkins, 1985). When studying Sierra Nevada bedrock channels, it is necessary to perform a critical assessment 
of how non-uniform lithology contributes to local rates of erosion and the formation of knickpoints. The goal of this study was to better understand the relationship between lithologic variation and channel morphology in the Sierra Nevada. How variation in lithology affects knickpoint formation and preservation were investigated by directly comparing river longitudinal profiles to mapped geologic units and by investigating the bedrock above and below channel knickpoints. A mapped geologic or lithologic unit is defined here as an individually distinct bedrock type identified on geologic maps.

Knickpoints were expected to occur repeatedly at mapped lithologic contacts and to occur at a higher frequency where more resistant substrate is up-river from weaker bedrock.

\section{METHODS}

\section{Field Site}

The Sierra Nevada Mountain range extends roughly $650 \mathrm{~km}$ in eastern California (e.g., Bateman and Wahrhaftig, 1966; Gabet, 2014). The mountains are composed of a geologic patchwork, with rocks varying in grain size, modal mineralogy, and fabrics, making the region ideal for studying the controls on knickpoint formation in heterogeneous granitic environments (e.g., Bateman and Wahrhaftig, 1966; Heitanen, 1973; Calkins, 1985). To investigate the spatial distribution of knickpoints, longitudinal profiles were extracted from 10-m DEMs of the western slope of the northern and central Sierra Nevada (USGS National Elevation Dataset, 2014). Because of the availability of high resolution geologic maps near the Feather and Merced rivers, these river networks were analyzed and compared to their underlying rock type. 
The Feather River is a main tributary to the Sacramento River on the northwestern slope of the Sierra Nevada mountain range (Fig. 1). The Feather River (Fig. 2) network flows through a variety of diorites, volcanic rocks, and variety of metamorphic rocks (Hietanen, 1973). The regional environment supports a diverse vegetation community of conifer and deciduous forests (Huang et al., 2012). The region has a mean annual temperature of $12{ }^{\circ} \mathrm{C}$, an average precipitation of about $178 \mathrm{~cm}$, and a Mediterranean climate with warm, dry summers and wet, cold winters (Huang et al., 2012; Feather River Coordinated Resource Management, 2013). The mapped geologic units used to compare channel slope and underlying lithology were obtained using the Hietanen (1973) geologic map. 


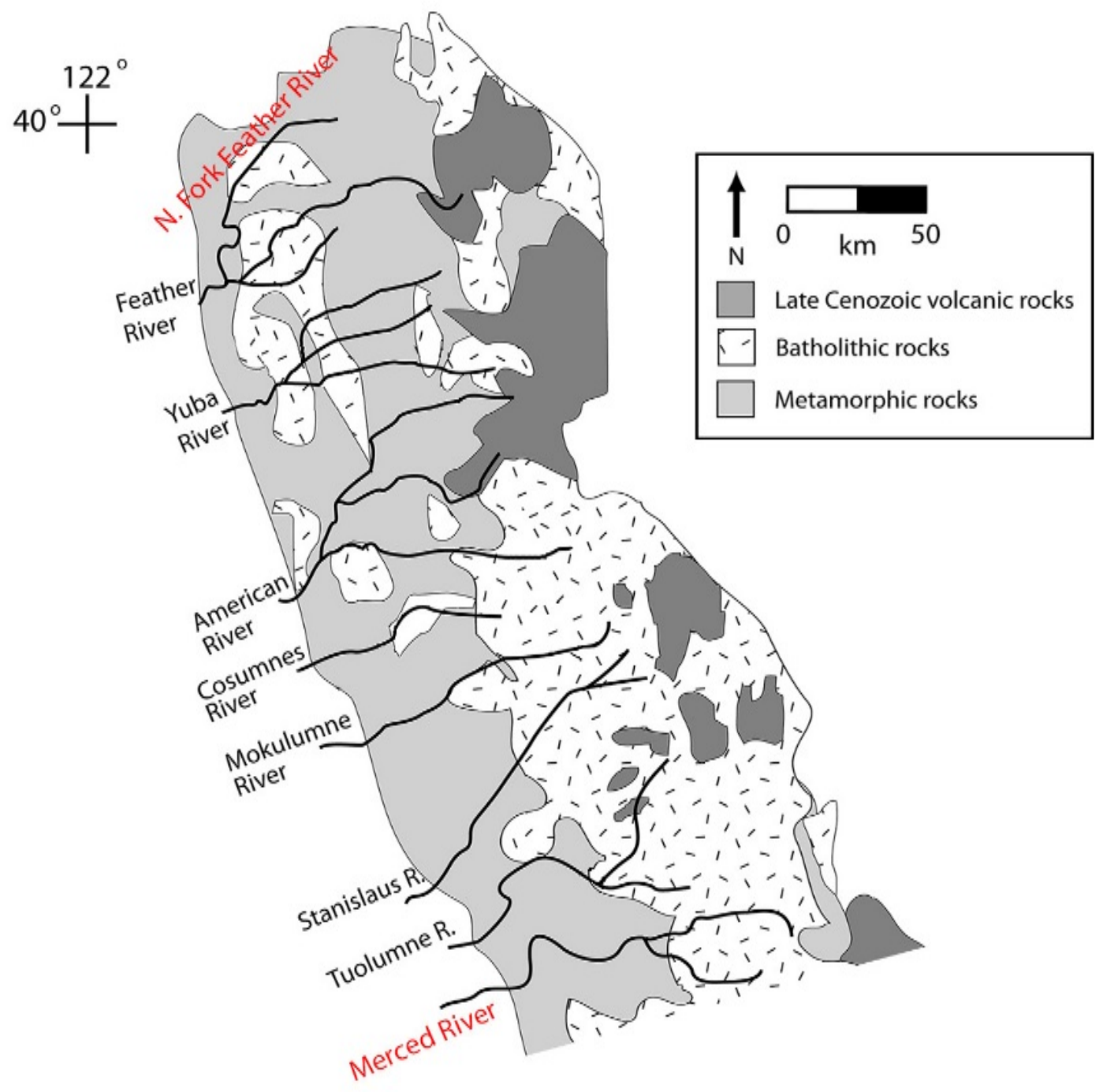

Figure 1. Map showing main rivers on the western slope of the central and northern Sierra Nevada. The Merced River and North Fork Feather River (highlighted in red) are investigated in this study. Taken from Gabet (2014). 


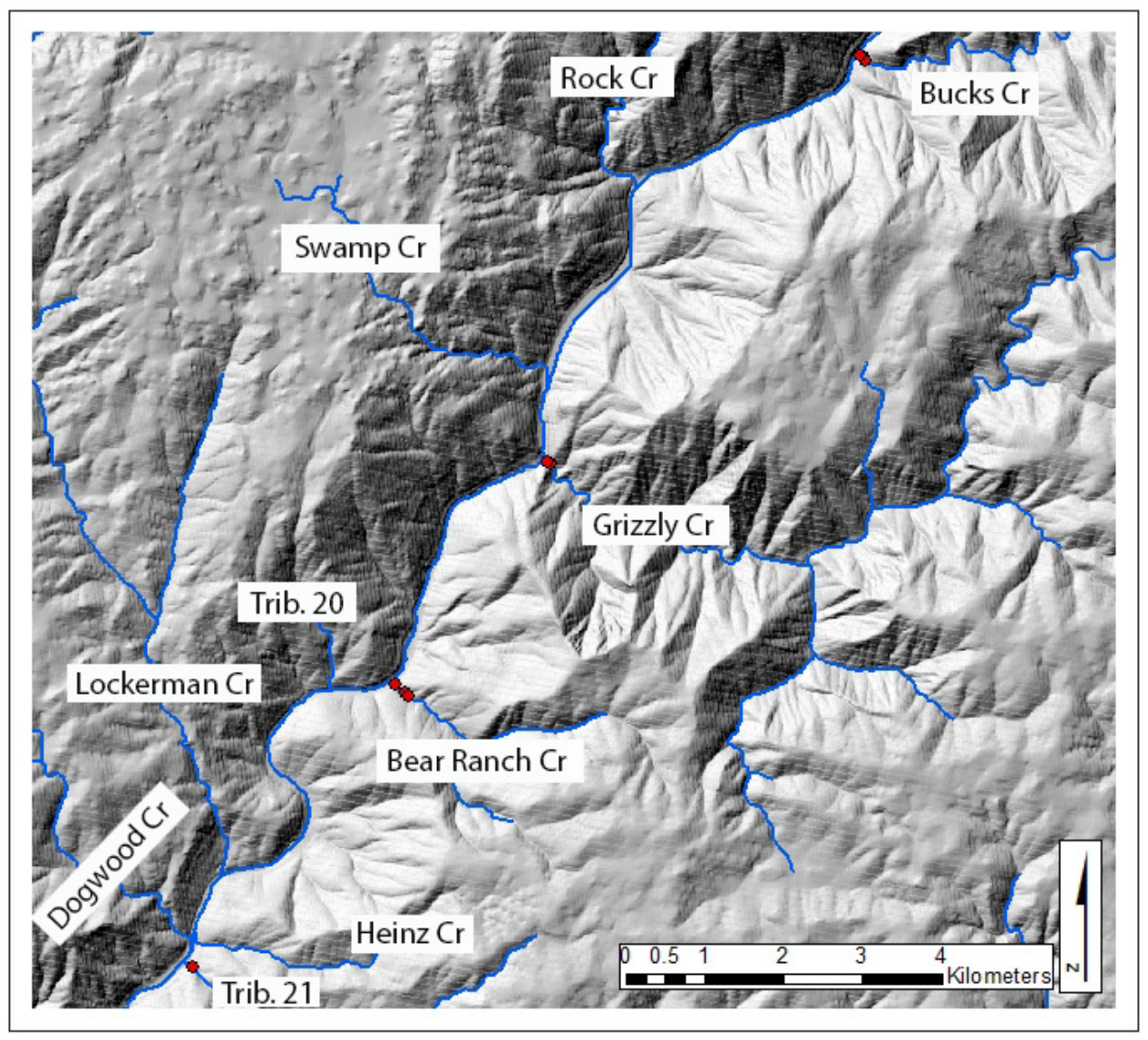

Figure 2. Topography, tributaries, and bedrock sample locations along the North Fork Feather River. The red dots and blue line represent the bedrock sample locations and the river network respectively. The 10 meter resolution elevation data is from the National Elevation Dataset, U.S. Geologic Survey (2014).

The Merced River (Fig. 3) is a large tributary to the San Joaquin River in the central

Sierra Nevada. Similar to the Feather River, the Merced has a Mediterranean climate, but with a slightly higher mean annual temperature of $16^{\circ} \mathrm{C}$ and a lower average annual rainfall of $41 \mathrm{~cm}$ (Harden, 1987). The Merced River flows over alluvium, talus, Cretaceous granodiorites, Cretaceous granites to gabbros and Pre-Cretaceous metamorphic rocks (Calkins, 1985). The vegetation in the Merced watershed consists primarily of annual grasses, oak forest, riparian vegetation and grazed grasslands 
(Harden, 1987). The mapped geologic units used for this study area were extracted from the USGS Bedrock Geologic Map of Yosemite Valley, Yosemite National Park, California (Calkins, 1985). 


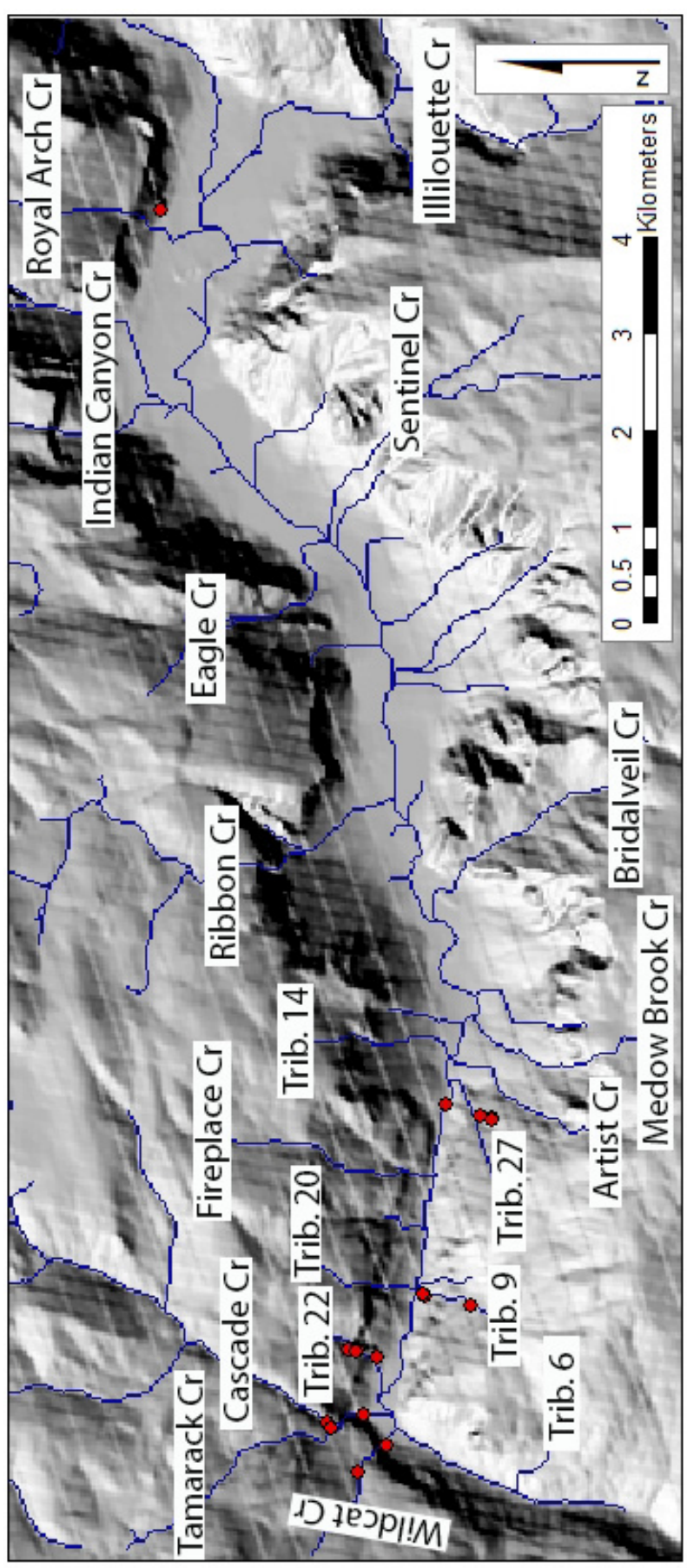

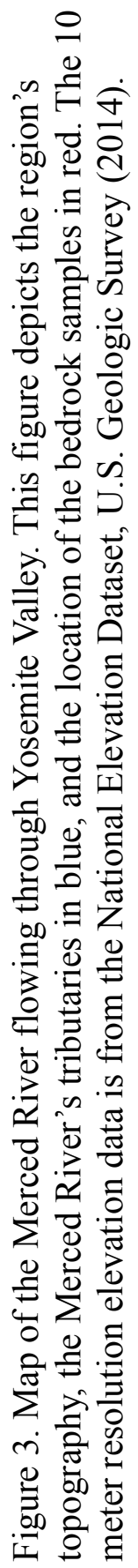




\section{Longitudinal Profile Analysis}

Channel slope is partially dependent on the total discharge, and as discharge increases the local channel gradient is less affected by the underlying geology (e.g., Stock and Montgomery, 1999; Duvall et al., 2004; Pederson and Tressler, 2012). When studying channel slope, discharge is typically substituted by drainage area (Pederson and Tressler, 2012; Equation 1). Increases in discharge, such as those that are expected at tributary junctions, may create channel knickpoints, and can introduce false positives when identifying convexities corresponding to lithologic variation. To account for knickpoints caused by instantaneous flow increases, longitudinal profiles were compared to the drainage area using Gabet's Profiler Tool (Gabet, 2013). Comparing channel longitudinal profiles to the drainage area helped identify slope changes associated with increased discharge.

DEMs were used to extract the flow accumulation, flow direction, and stream network data inputs for the Profiler Tool. Gabet's Profiler Tool plots a channel's longitudinal profile with the area accumulation data. The longitudinal profiles created with these tools were compared to the mapped underlying geology to identify profile convexities specifically caused by obvious lithologic or textural transitions.

\section{Field Analysis}

After the locations of channel knickpoints were identified with the DEM analysis, their spatial distributions were analyzed to determine if statistically significant relationships between bedrock lithology and incision exist. The field analysis consisted of 
three primary elements: ground-truthing the knickpoints found in the longitudinal profiles; extracting bedrock samples for laboratory analysis; and identifying any unmapped knickpoints.

To ensure that the longitudinal profile knickpoints were not artifacts of DEM data gaps, as many of the channels that could be safely accessed were physically examined. Due to field conditions, safety concerns, and available equipment, only the bedrock from above and below the knickpoints of eight tributaries could be accessed for groundtruthing and sampling. Walking the streams helped identify the mapped knickpoints and contributed to a qualitative understanding of the bedrock channel's underlying geology.

After the knickpoint and geologic units were identified, unweathered bedrock samples above and below the knickpoint were collected to quantify grain size and mineralogy. All the bedrock samples were collected from the channel bed. Samples, between 15 and $60 \mathrm{~cm}$ in length and width, were extracted using a rock hammer. The samples were taken back to the laboratory to examine the mineralogical and grain size differences of the bedrock above and below channel knickpoints. Although many knickpoints visible in the field were not expressed in the 10-m resolution longitudinal profiles, all ground-truthed knickpoints were used in the statistical analysis of bedrock grain size and mineralogy.

\section{Mineral and Textural Analysis}

Before the minerals were manually counted, the samples were cleaned, cut, chemically stained, and digitally photographed. Using a rock saw, the samples were cut 
into flat slabs large enough to be representative of the entire sample; this was usually between $7 \times 7$ and $20 \times 20 \mathrm{~cm}$. After the samples were cut into slabs, the feldspars were stained to efficiently differentiate between potassium and plagioclase feldspars (Jackson and Ross, 1956). The rock slabs were first etched with $48.9 \%$ hydrofluoric acid for 20 seconds and cleaned with DI water. The freshly etched surfaces were then placed into a saturated solution of sodium cobaltinitrite for one minute, which stained the potassium feldspar a distinct yellow. Afterwards, the slabs were thoroughly rinsed with DI water and placed under a hot lamp for 5 minutes. Once the slabs had cooled, they were placed into an amaranth solution (made with $0.75 \mathrm{~g}$ of Red No. 2, 92\% pure coal tar dye, and $50 \mathrm{ml}$ of DI water) for 15 seconds and thoroughly rinsed, which stained the plagioclase feldspar red.

After the rock samples were cut and stained, the resulting slabs were digitally photographed with a transparent $10 \mathrm{~cm}$ ruler. Samples were photographed using a standard digital camera and analyzed using Photoshop ${ }^{\mathrm{TM}}$. The photographed ruler was used as a scale to rapidly construct the transects and grids used in the mineral counts. This study defined bedrock texture as the average mineral grain size found in the bedrock matrix (Migon and Vieira, 2014). To quantify bedrock average grain size, each crystal along a transect was counted. Quantifying the number of mineral grains per centimeter allowed for average grain sizes to be compared statistically. Using Photoshop ${ }^{\mathrm{TM}}$, 5-15 transects each $5-10 \mathrm{~cm}$ in length were digitally drawn onto the photographed samples. Crystals along the digital transect were counted and digitally marked using the photo editor tools to prevent miscounts. Some samples had intrusions or a varied mineral 
textures, requiring numerous transects per slab for a representative sample. For example, if a rock slab were $5 \times 5 \mathrm{~cm}$ with uniform textures and it had a vein or dine $1 \times 5 \mathrm{~cm}$ wide, $1 / 5$ of the transects (which would be $5 \mathrm{~cm}$ in length) were dedicated to that $1 \mathrm{~cm}$ intrusion. The transects were then averaged to obtain the grain size of that sample. A variation of Jackson's and Ross' (1956) methods for modal analysis on medium- to coarse-grained rock slabs was used to investigate mineralogy. Their method was created specifically for the rapid modal analysis of Sierra Nevada rocks; however, the accuracy of their method diminishes when samples have grain sizes of less than $2 \mathrm{~mm}$ (Jackson and Ross, 1956). Advances in digital photography and image processing circumvent this limitation, allowing for the technique to be applied to rock slabs with grain sizes less than $2 \mathrm{~mm}$ when crystals are not aphanitic. To perform the modal analysis, Jackson and Ross (1956) placed a gridded overlay on a rock slab face and recorded each mineral touching a dot on the random pattern overlay. Mimicking their technique in Photoshop ${ }^{\mathrm{TM}}$, a digital grid was overlain onto the photographed slab surface. The grid pattern was scaled to have uniform boxes that were slightly larger than the largest crystal present in the sample. The mineral directly below each grid intersection was identified and recorded. Similar to the grain size method, the minerals were individually counted and digitally marked to prevent miscounts. Depending on the slab surface area and the mineral size of the sample, roughly 300-3000 individual points were collected per sample. The examined minerals were limited to the easily identifiable minerals that are known to influence the strength of granites: quartz, plagioclase feldspar, potassium feldspar, and undifferentiated mafic minerals (Tugrul and Zarif, 1999; Sousa, 
2012). Minerals that were not in one of those categories were identified as 'other' for the purpose of obtaining accurate mineral percentages. Although biotite is often identified as a significant mineral involved in the chemical erosion of granites (Wahrhaftig, 1965; Lagasquie et al., 2012; Migon and Vieira, 2013), it was combined with the other dark minerals because of the difficulty differentiating between biotite and hornblende in hand samples (Jackson and Ross, 1956).

Grain size and modal mineralogy data from the bedrock samples above and below the knickpoint were compared statistically using a t-Test that assumes unequal variances. If the P-value is less than 0.05 , the differences in bedrock grain size and modal mineralogy above and below the knickpoint are assumed to be statistically significant.

\section{RESULTS}

\section{Longitudinal Profile Analysis}

A comparison of the longitudinal profiles and the mapped geologic units reveal that bedrock channel knickpoints are often coincident with lithologic contacts. A majority of the tributaries examined appear to have at least one example of a knickpoint forming at a lithologic contact (Figs. 4-D, 4-E, 5 B-D; Appendix 1-B, 1-C, 1-E, 1 G-J, 2-E). Although bedrock channel knickpoints frequently occur at lithologic transitions, a knickpoint is not always present at lithologic contacts and knickpoints often develop within mapped lithologic units (Figs. 4 A-E, 5 A-D). Individual lithologic units, identified by the Pulgas and Buck's Lake and the Yosemite Valley geologic maps, were found to have enough mineralogic and textural variation to affect channel slope. 


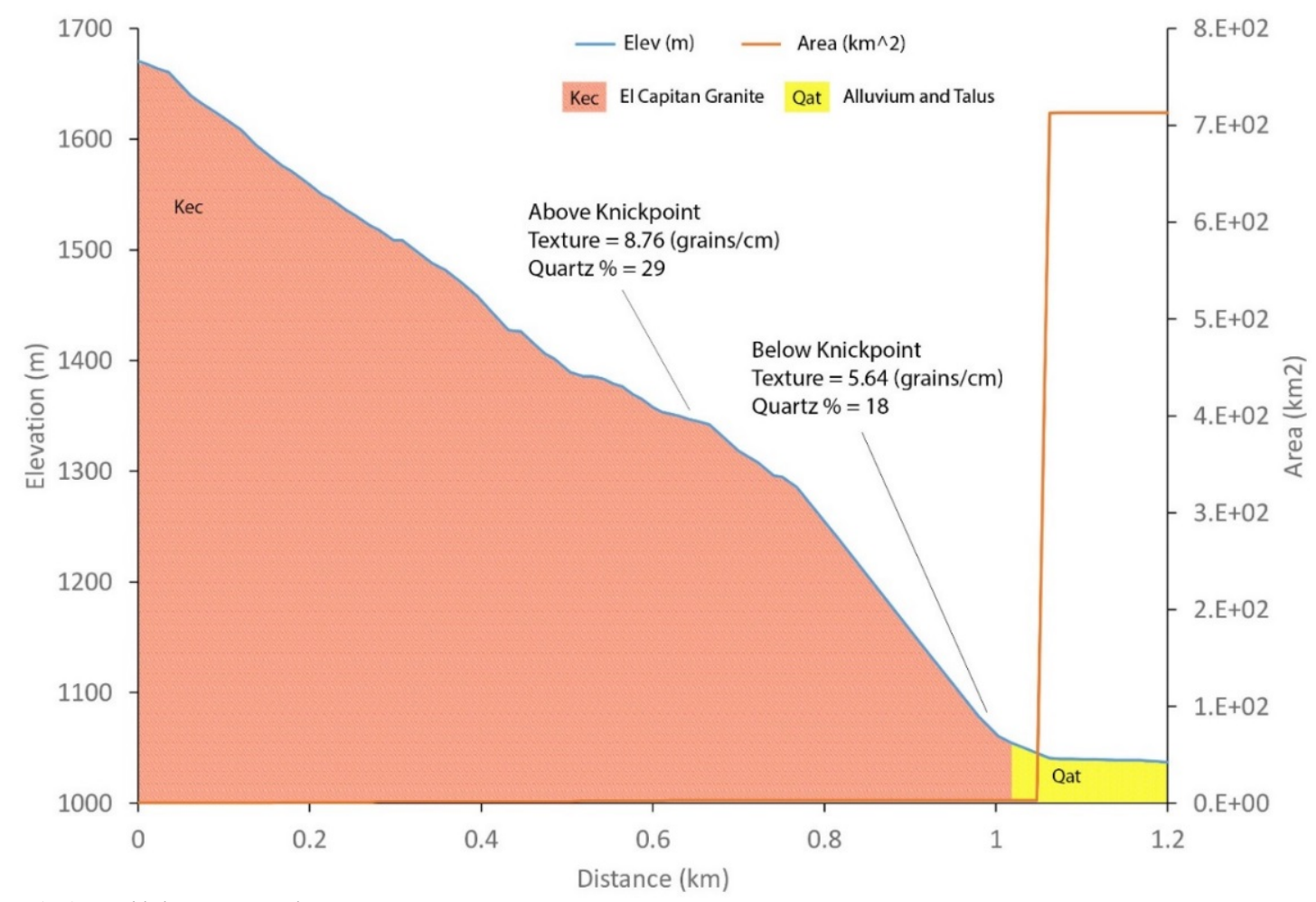

(A) Wildcat Creek

Figure 4. Longitudinal profiles of the Merced River tributaries compared to their underlying lithology. Figures 4A-4E are limited to the tributaries sampled in the field, and display the locations of each bedrock sample. Knickpoints are clearly seen as breaks in slope along the channel profile. The additional figures comparing the underlying geology to the channel profile can be found in the appendix. The blue line represents the longitudinal profile elevation and the orange line represents the drainage area. The orange line increases rapidly at the junction of the tributary with the Merced River. Figure 4-A is Wildcat Creek, Figure 4-B is Cascade Creek, Figure 4-C is Tamarack Creek, Figure 4-D is an unnamed tributary arbitrarily labeled 22, and Figure 4-E is Royal Arches Creek. 


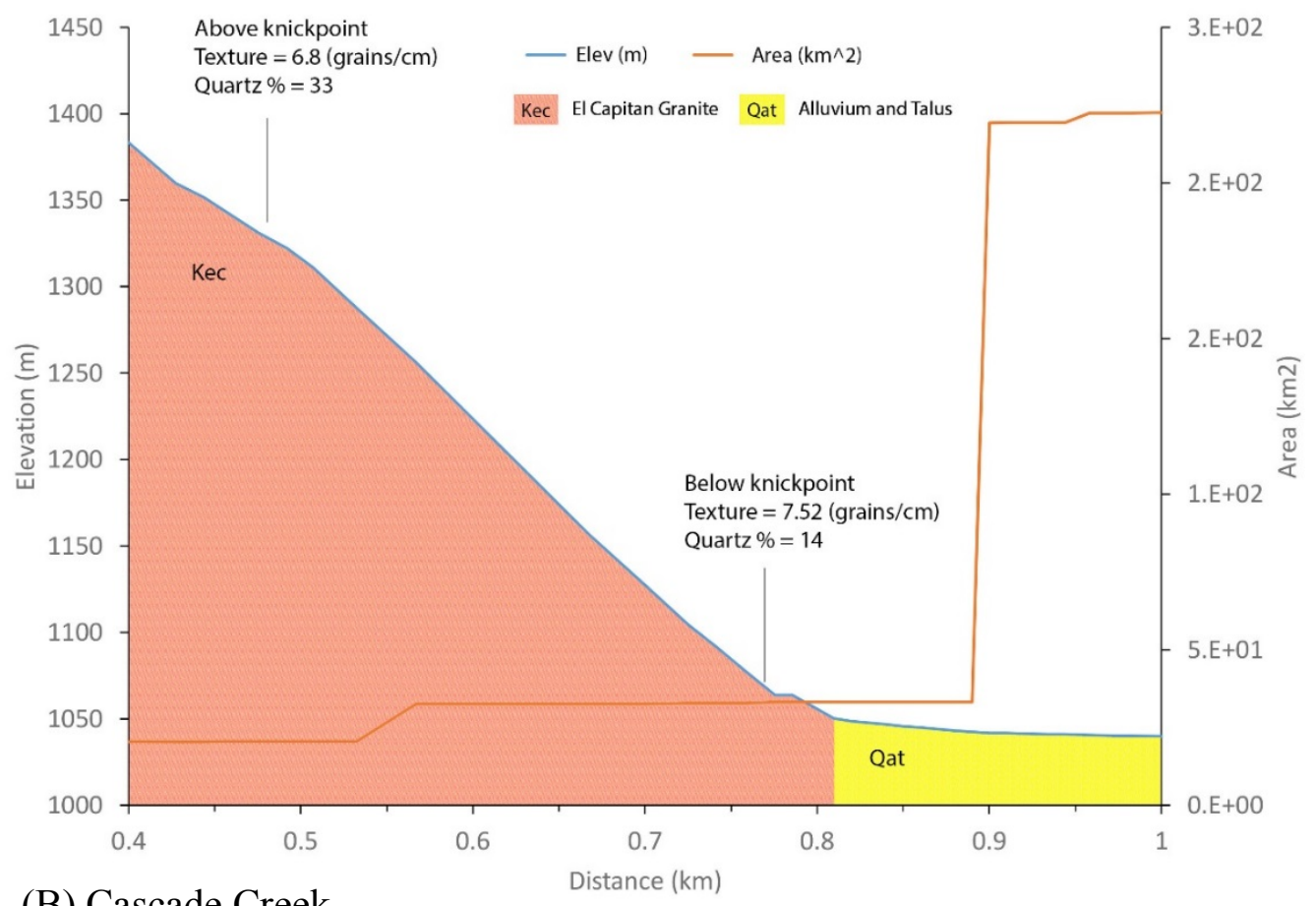

(B) Cascade Creek

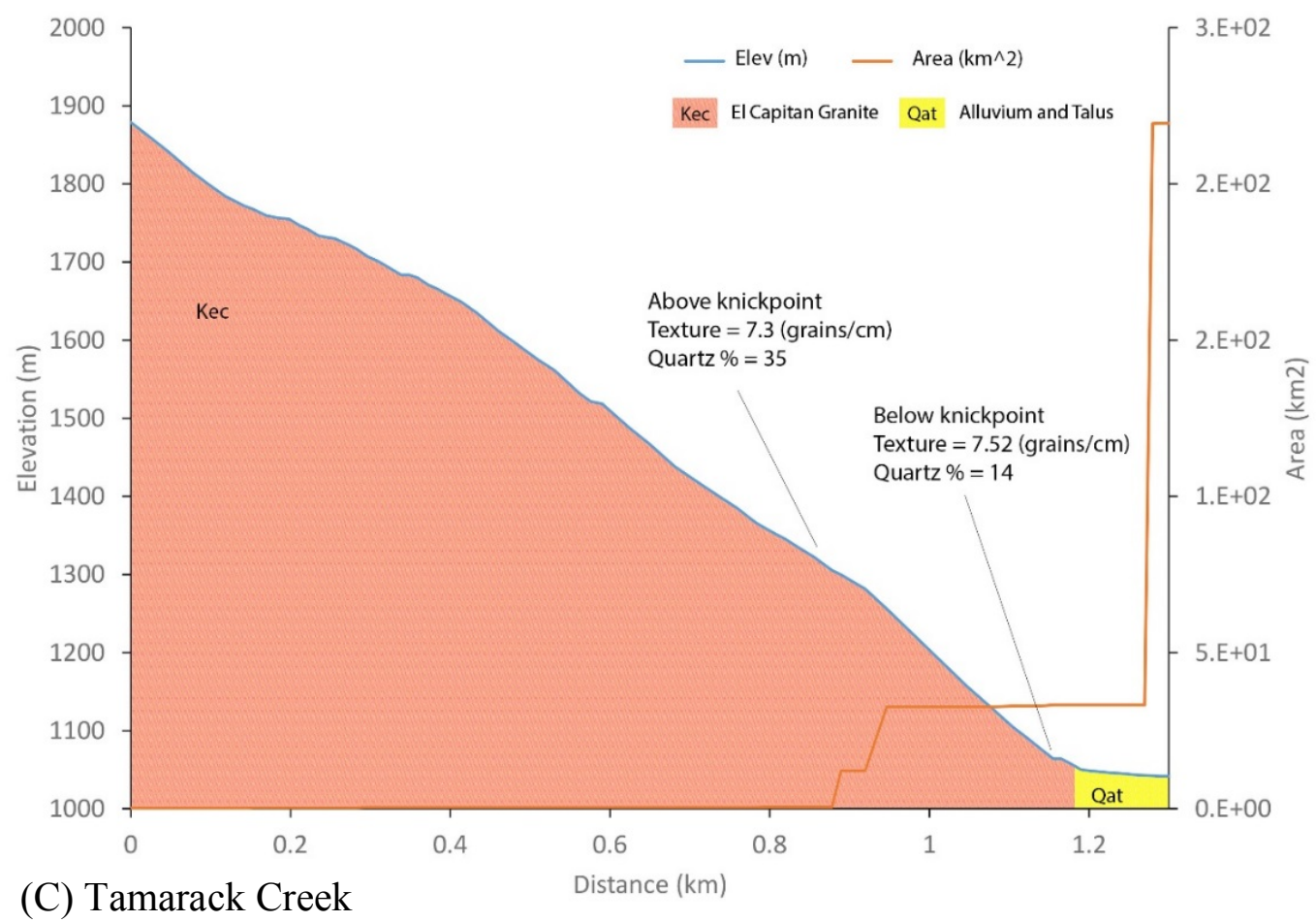




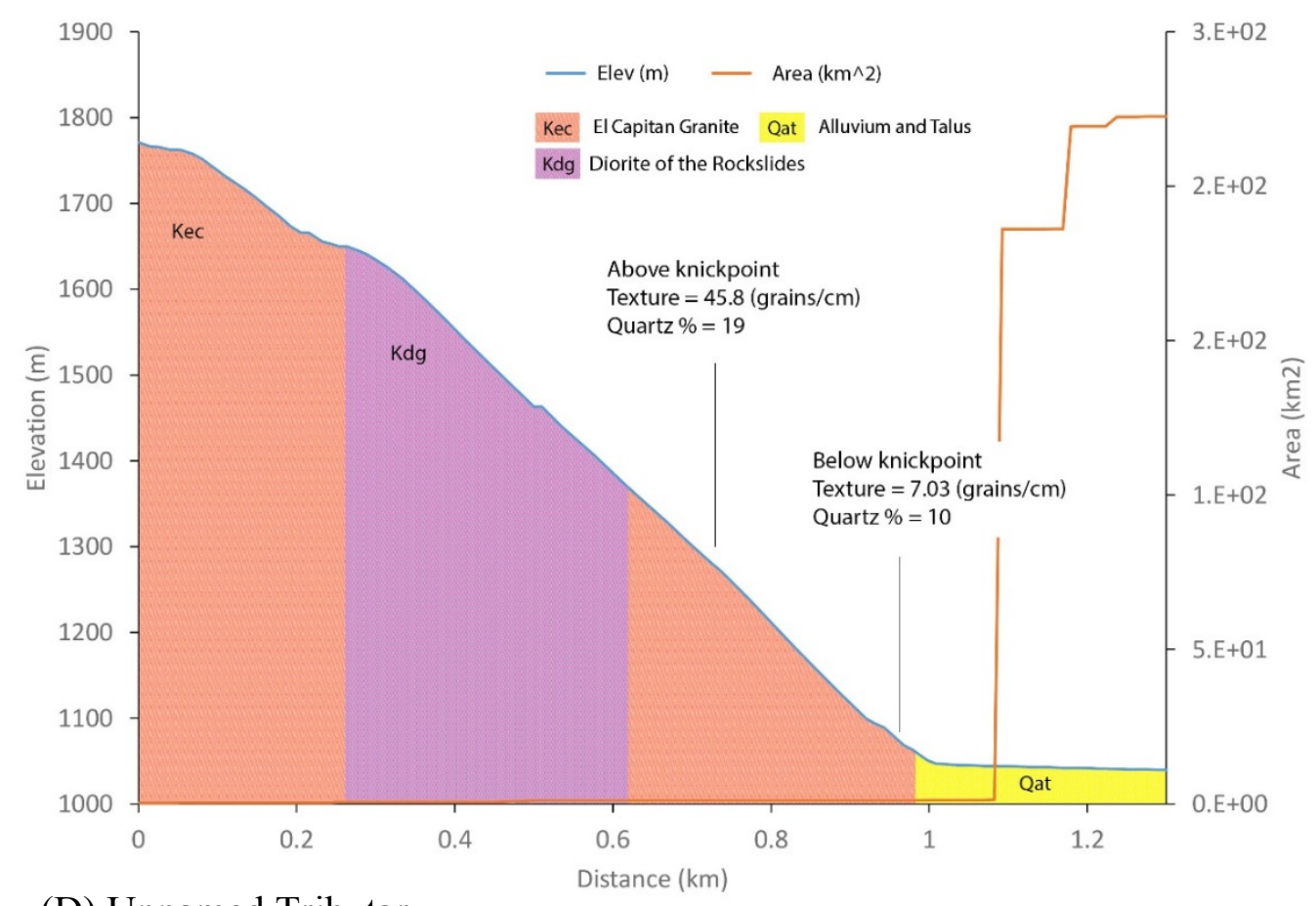

(D) Unnamed Tributary

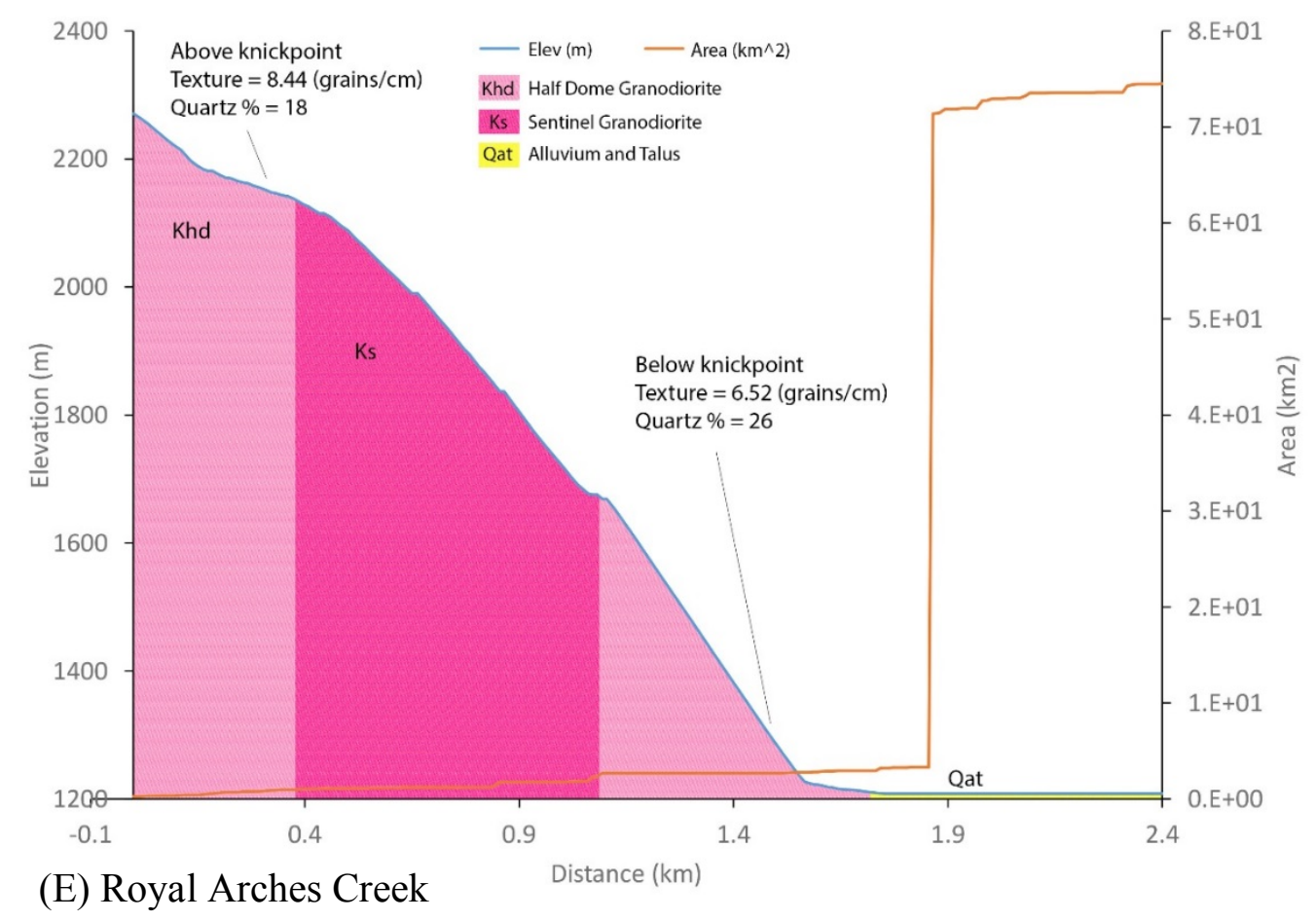




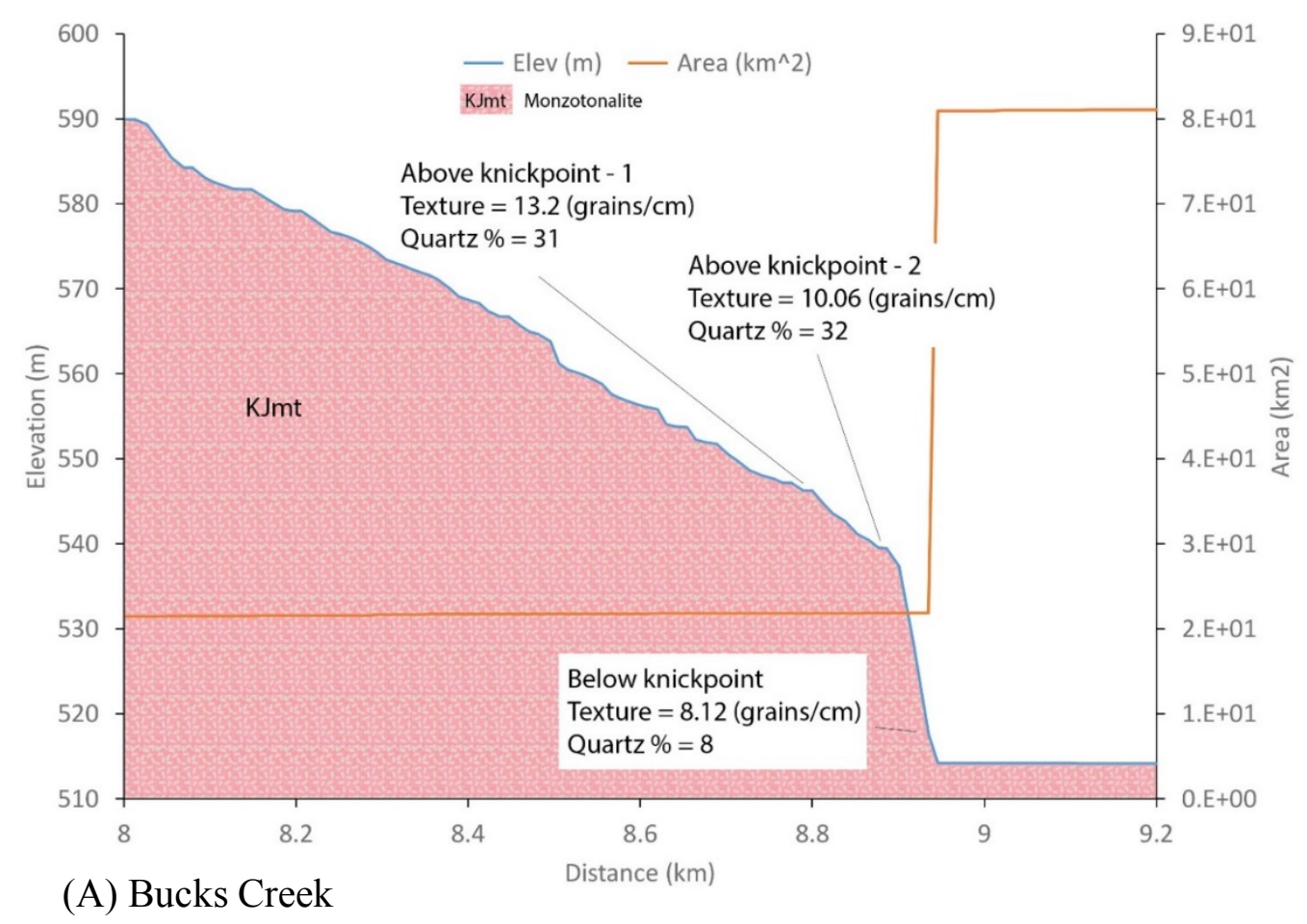

Figure 5. Longitudinal profiles of the Feather River tributaries are compared to their underlying lithology. This figure is limited to the tributaries sampled in the field, but the additional figures that compare longitudinal profiles to the underlying lithology can be found in the appendix. Similar to the tributaries of the Merced River, the Feather River tributaries have been plotted against the drainage area to ensure profile knickpoints are not caused by increases to discharge. Figure 5-A is Bucks Creek, Figure 5-B is Bear Ranch Creek, Figure 5-C is Grizzly Creek, and Figure 5-D is an unnamed tributary arbitrarily numbered 21 . 

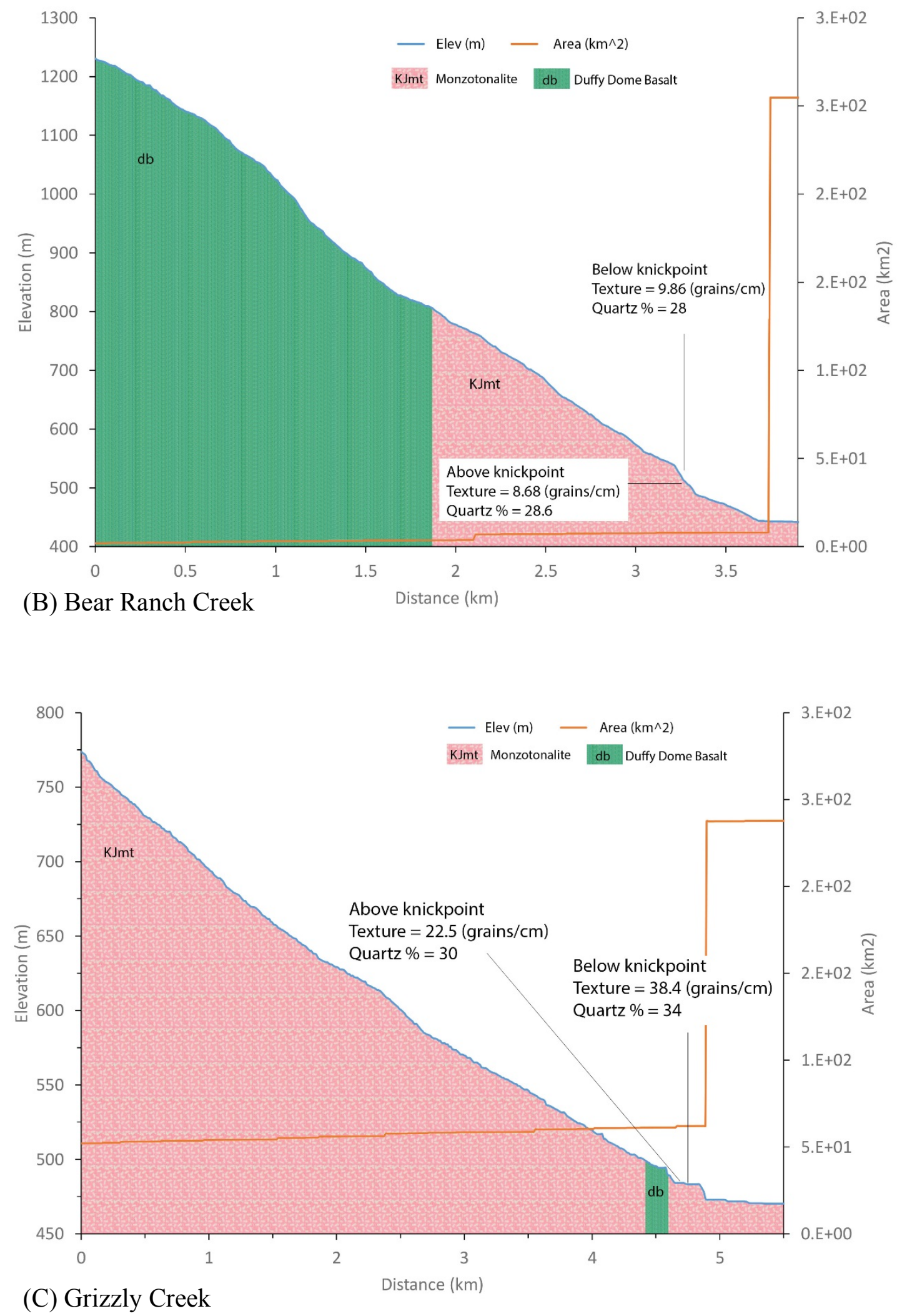


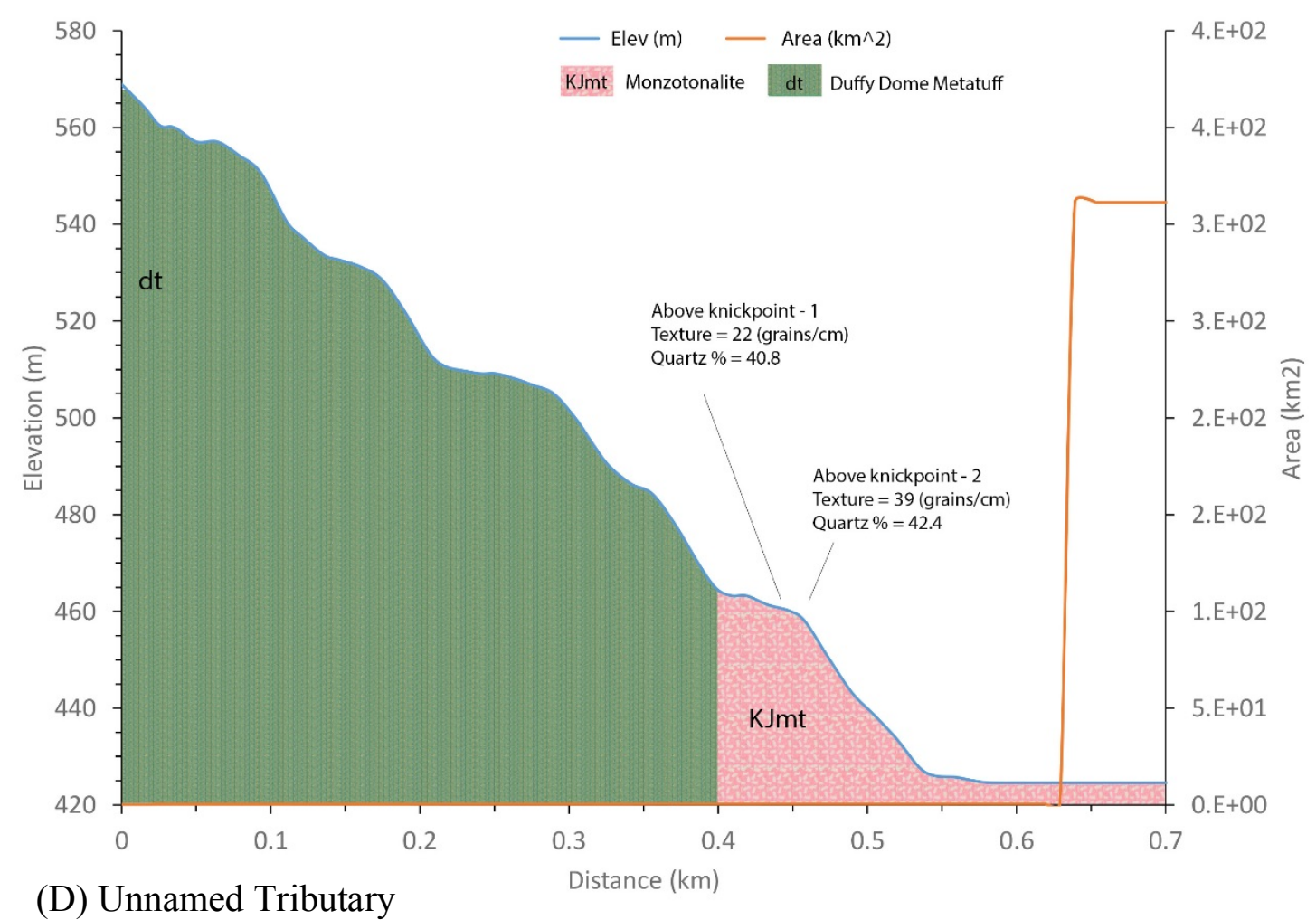

\section{Grain size}

The following results and discussion sections are limited to channels examined in the field and laboratory. Of the bedrock attributes analyzed, the differences in grain size above and below knickpoints are the most statistically significant (Tables 1,2$)$. The bedrock found below knickpoints is coarser-grained and the grain size data have a lower standard deviation (10.3 grains/cm) than the bedrock above the knickpoints (Table 1;

Figs. 4, 5, 6-A). Conversely, the bedrock above knickpoints is more fine-grained than the bedrock below knickpoints, and the grain size data have a standard deviation of 14.4 grains $/ \mathrm{cm}$. The t-test used to compare the average grain size of the bedrock above and below the knickpoints yielded a P-value of 0.00028 , indicating that the bedrock grain size 
above the knickpoints are statistically different from bedrock below the knickpoints and may contribute to knickpoint formation in Sierra Nevada bedrock channels.

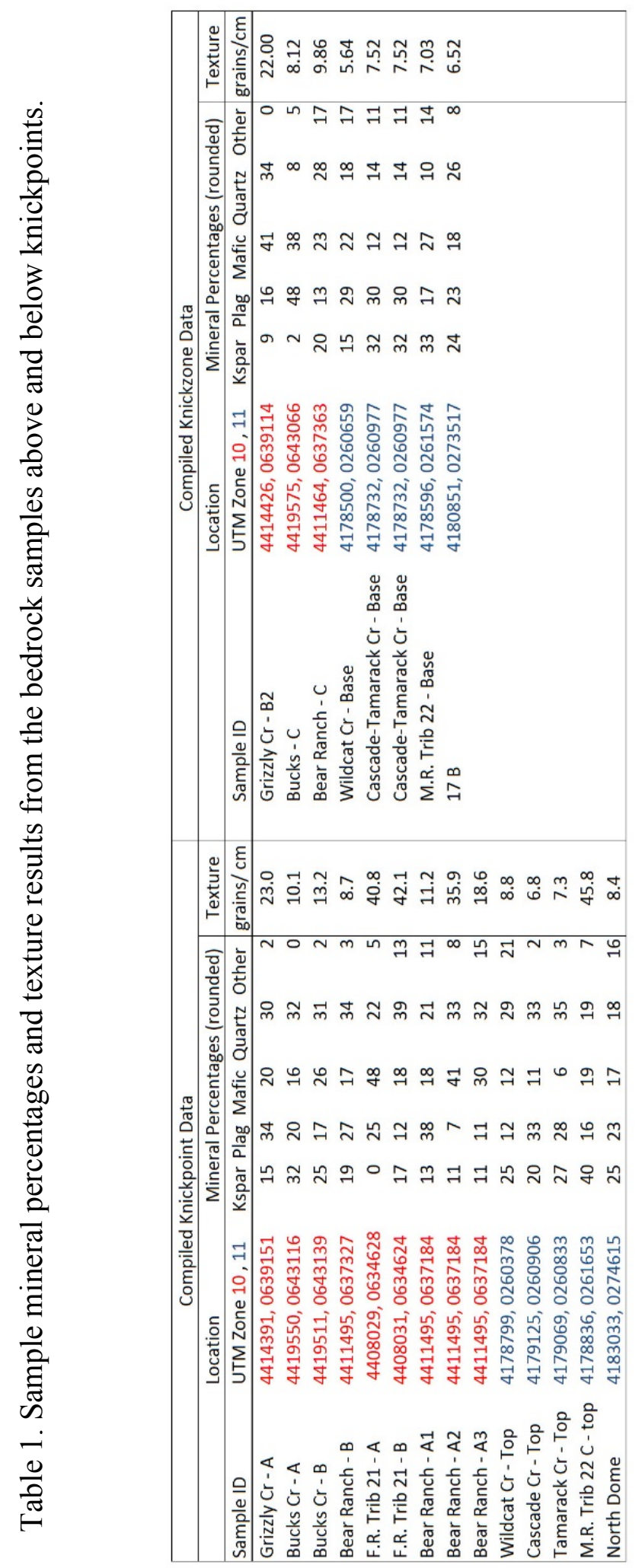




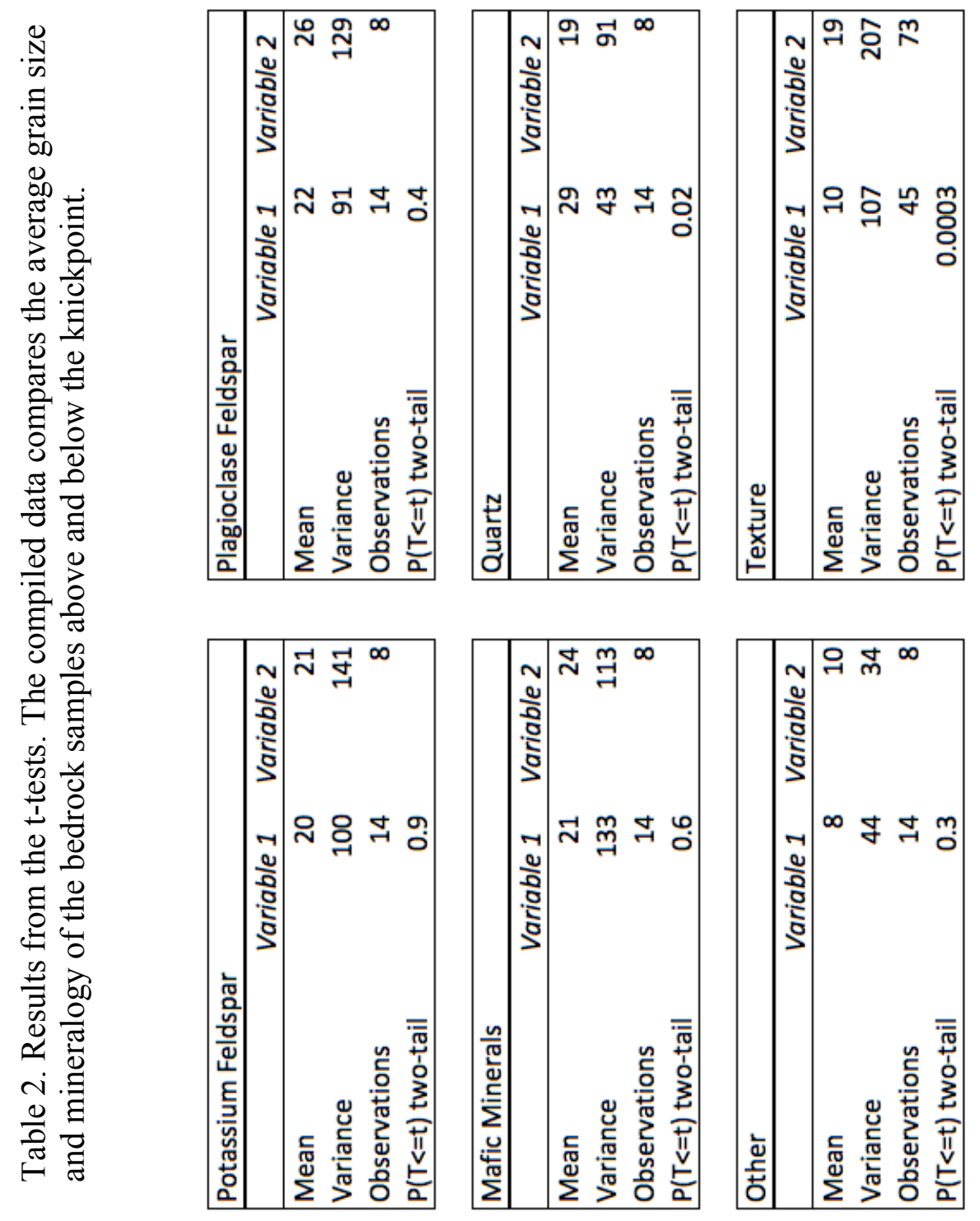




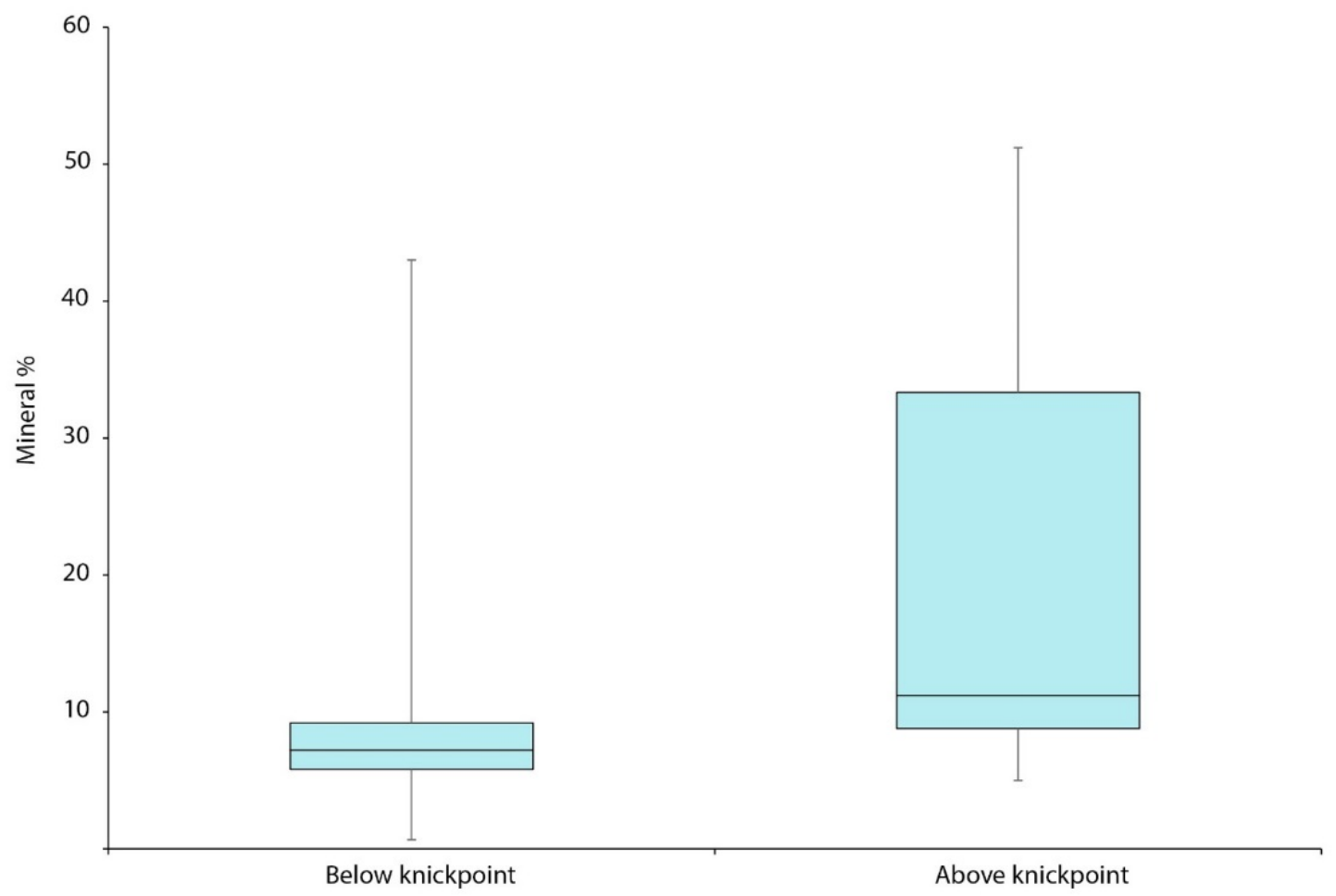

(A) Texture

Figure 6. The boxplots organize the data by bedrock samples above and below knickpoints, juxtaposing the rock grain size and mineralogy data at each location. Only differences in the bedrock grain size (Figure 6-A) and quartz content (Figure 6-B) were found to be statistically significant. The texture sample size is 118 and the P-value is equal to 0.0003 . For quartz, mafic minerals, plagioclase feldspar, and potassium feldspar, and other minerals, the sample size is 22 and the P-values are $0.02,0.6,0.41,0.88$, and 0.3 , respectively. 


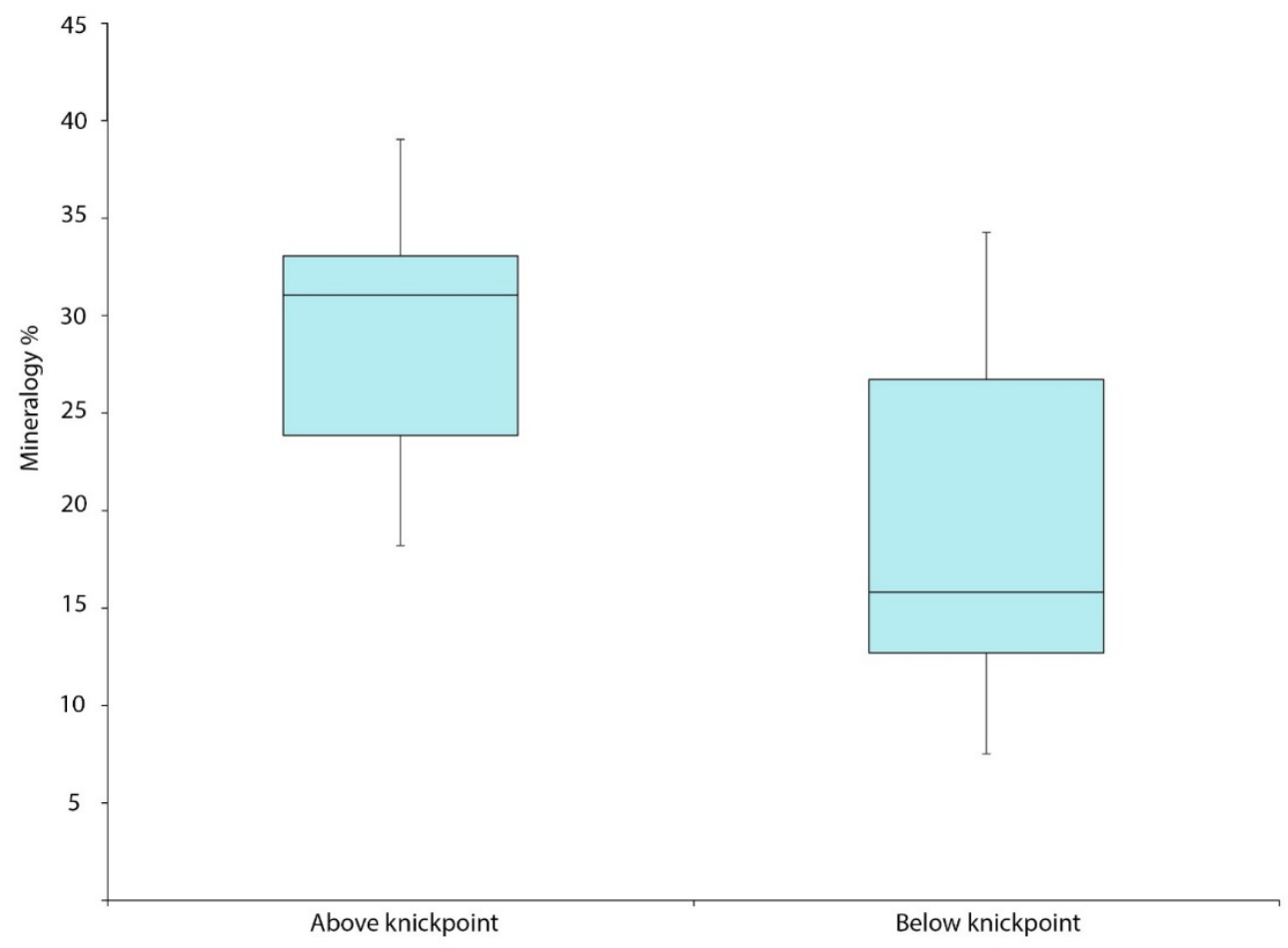

(B) Quartz

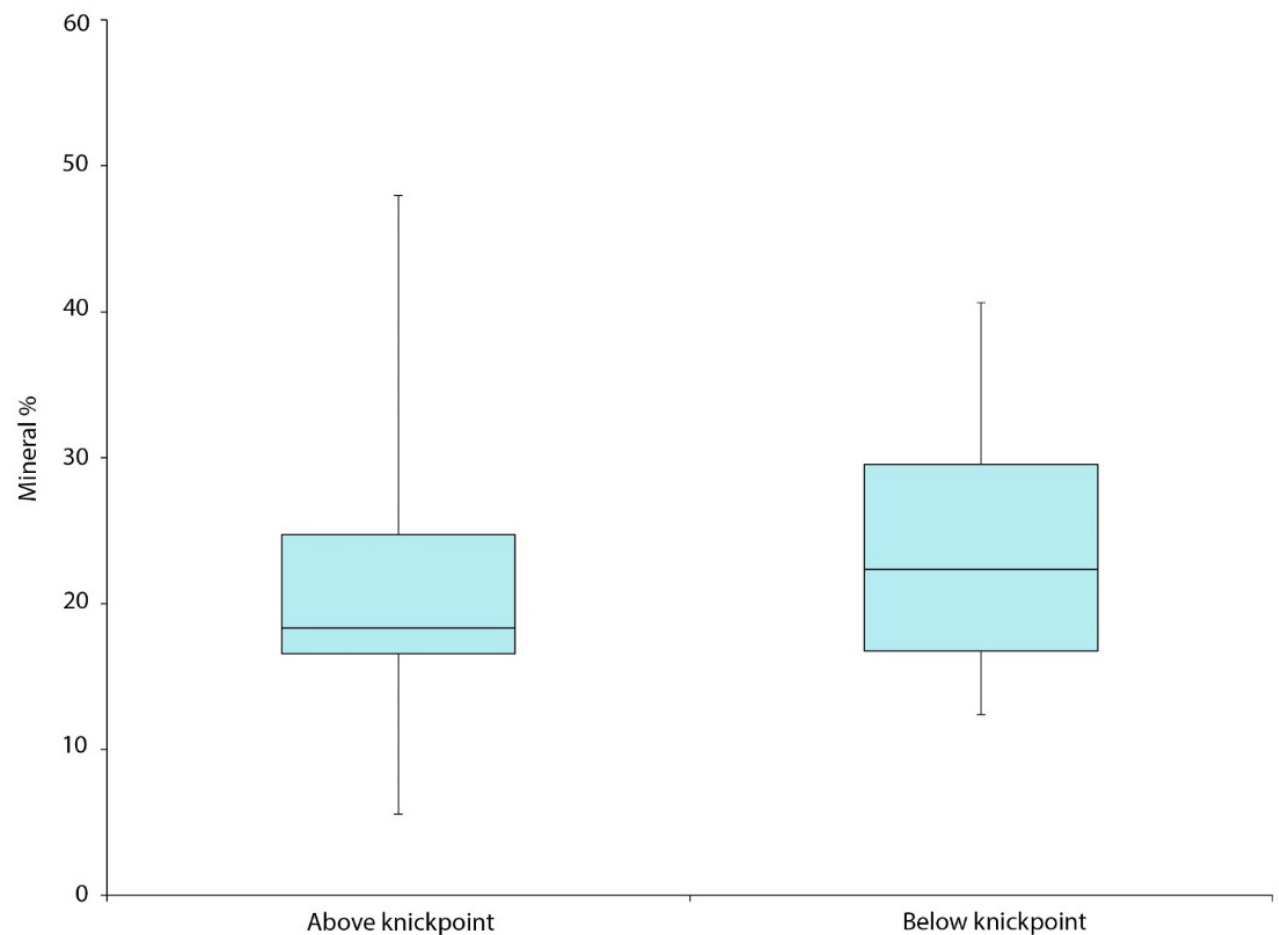

(C) Mafic minerals 


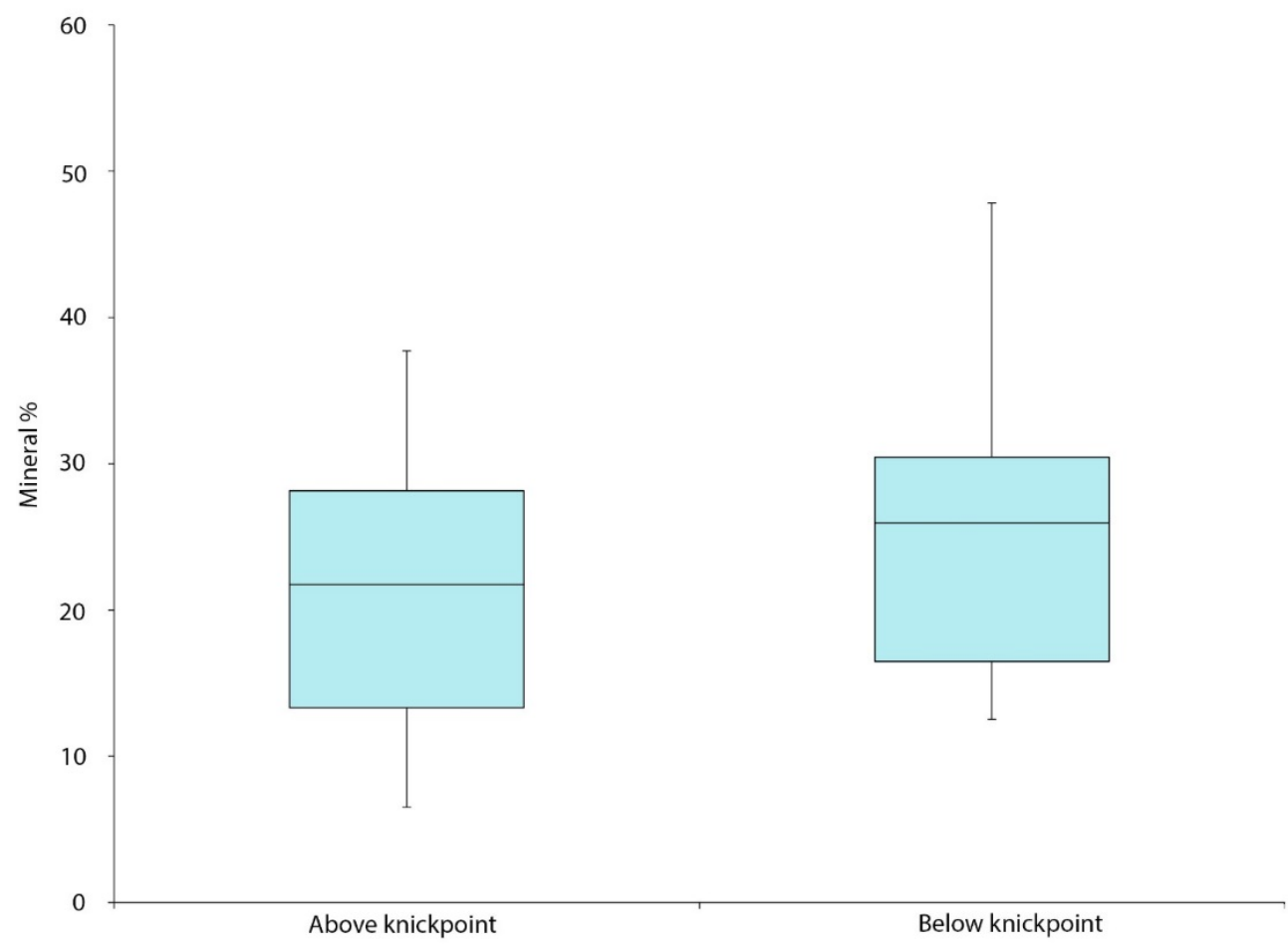

(D) Plagioclase feldspar

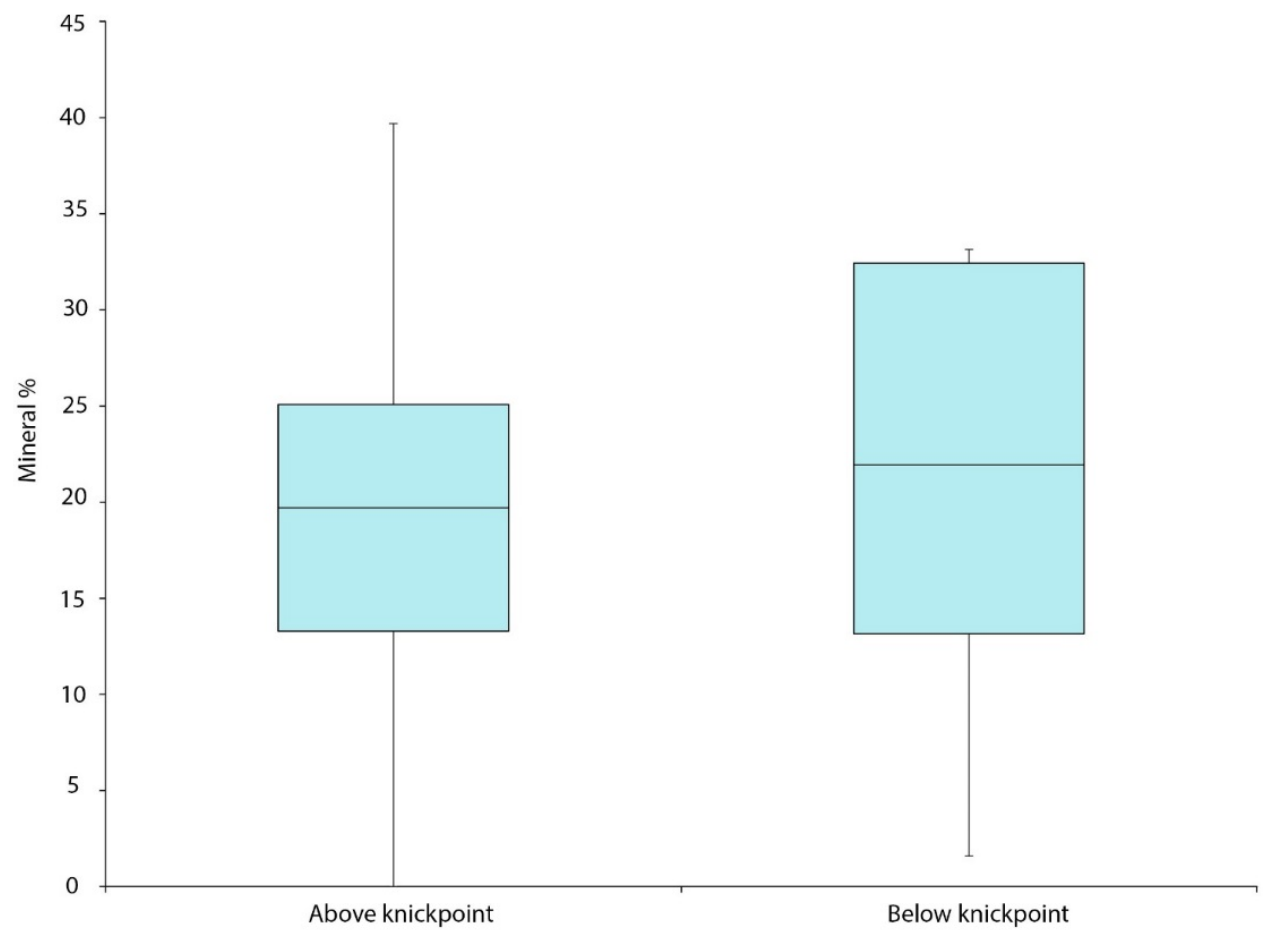

(E) Potassium feldspar 


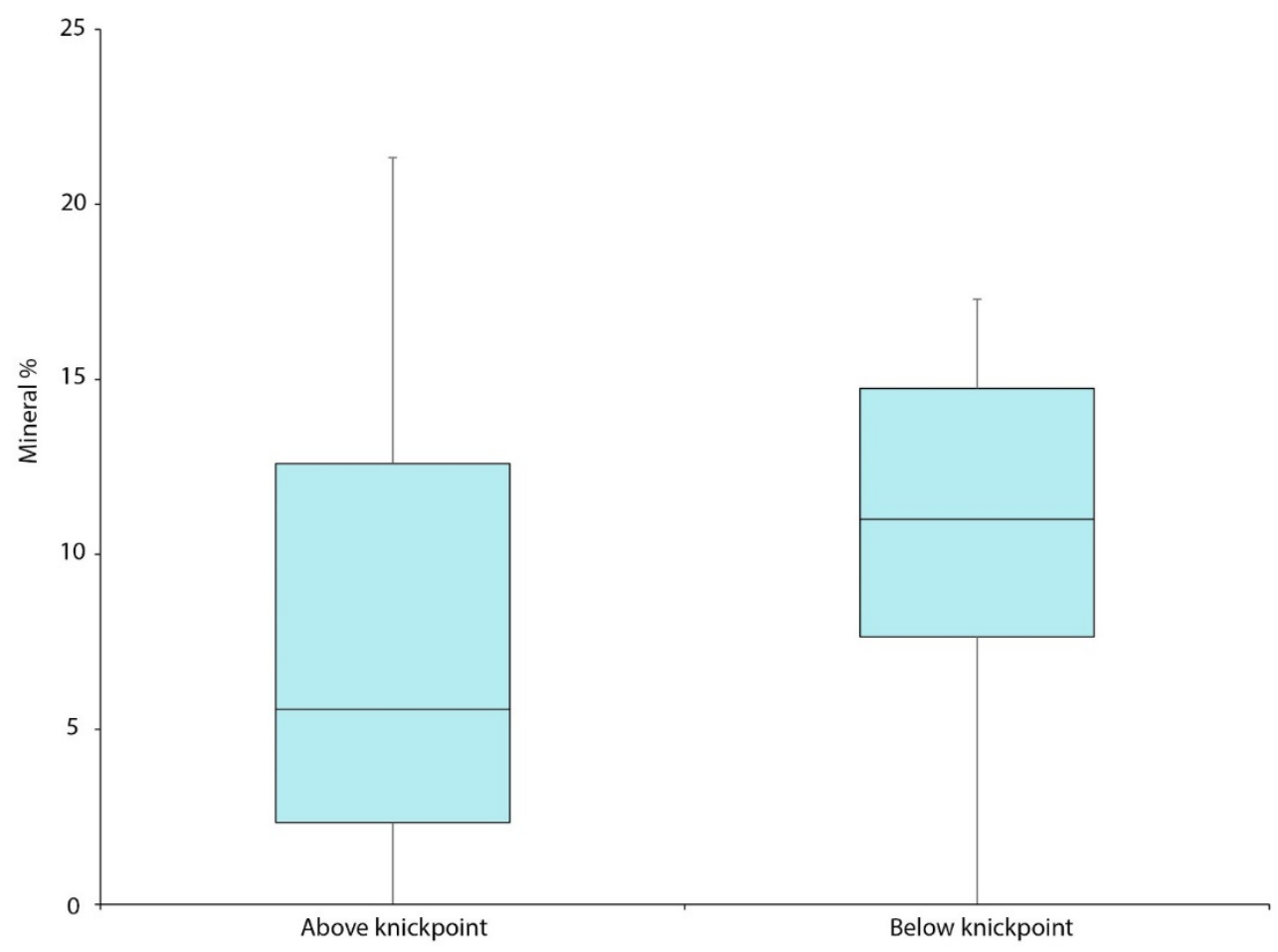

(F) Other minerals

\section{Mineralogy}

The quartz, plagioclase feldspar, potassium feldspar, and mafic mineral contents of each sampled bedrock slab were compared using a t-Test to identify any statistically significant differences in mineral content of the bedrock above and below channel knickpoints (Tables 1,2). When the percentages of plagioclase feldspar, potassium feldspar, and mafic minerals of bedrock above and below the knickpoints were compared, the $\mathrm{t}$-Tests yielded $\mathrm{P}$-values greater than 0.05 . Because the $\mathrm{P}$-values were greater than 0.05 , the bedrock content of these minerals were found not to be statistically different above and below the knickpoints (Tables 1, 2; Figs. $6 \mathrm{C}-\mathrm{F}$ ). The t-Test comparing the quartz content of the bedrock above and below knickpoints yielded a P-value of 0.02 , 
demonstrating that the differences in the percentages of quartz are statistically significant (Tables 1, 2; Figs. 6-B).

When the statistically significant bedrock characteristics, grain size and quartz content were compared to each other via linear regression, the relationship was found to be random (Figure 7). Thus, quartz content and average grain size are assumed to be two independent characteristics of granitic bedrock affecting channel slope.

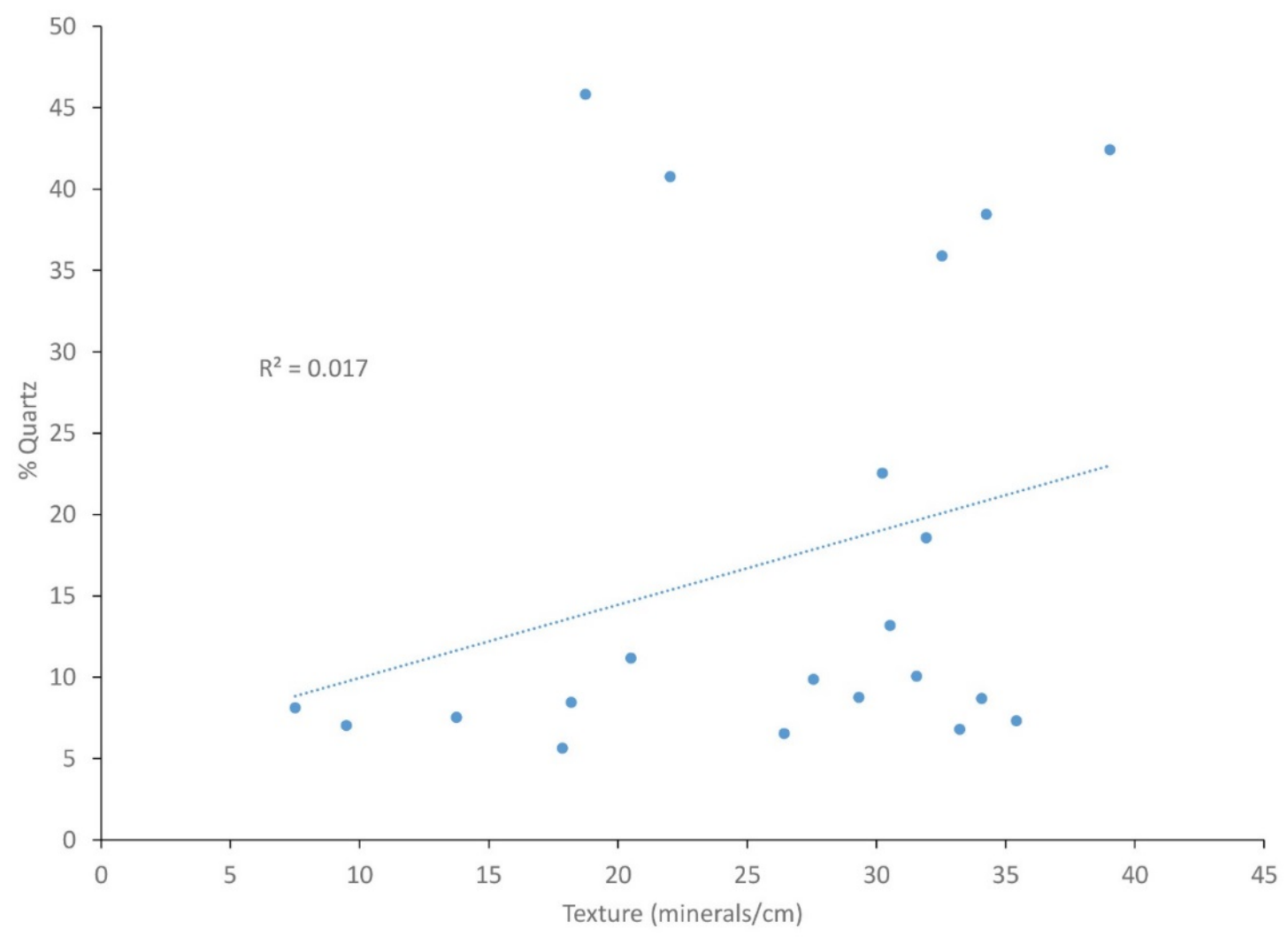

Figure 7. Quartz content and average grain size of bedrock above and below knickpoints. 


\section{DISCUSSION}

A bedrock's average grain size and quartz content are found to be statistically different above and below the knickpoints and may potentially predispose a channel to form a knickpoint. The Merced and Feather river tributaries demonstrate that bedrock above knickpoints consistently has textural and mineralogical characteristics associated with resistant lithologies, such as finer grain size and higher quartz content. Bedrock down-river from knickpoints often has attributes characteristic of easily erodible substrate, such as coarse-grain sizes and lower quartz content. Rock grain size and quartz content are two bedrock characteristics arguably contributing to the formation of knickpoints in Sierra Nevada bedrock channels.

Similar to previous work that identified correlations between underlying geology and patterns of erosion (e.g., Lagasquie et al., 2012; Migon and Vieira, 2014), this study demonstrates statistically significant differences in bedrock grain size and modal mineralogy above and below channel knickpoints. While the erosional resistance of granitic bedrock is notoriously difficult to quantify, geomorphic field studies in granitic environments reveal several trends. Resistant granite is generally characterized by equigranular texture, fine-grain sizes, and greater quartz content (Lagasquie et al., 2012; Sousa, 2012; Migon and Vieira, 2014). Weaker granites, prone to faster rates of erosion, usually have heterogranular textures, coarse-grain sizes, and greater amounts of biotite (Wahrhaftig, 1965; Lagasquie et al., 2012; Migon and Vieira, 2014). Determining if the bedrock above and below channel knickpoints contained heterogranular or equigranular textures, while important for future research, was beyond the scope of this project. 
This study demonstrates that bedrock channel knickpoints are often coincident with local transitions in rock grain size and quartz content, implying a correlation between knickpoint formation and instances of unequal bedrock resistance. This study finds evidence that erosion rates may be partially controlled by the matrix grain size and relative abundance of quartz in the bedrock fabric, suggesting that unequal hardness contributes to differences in rates of erosion and are expressed in channel form as knickpoints (Lagasquie et al., 2012; Migon and Vieira, 2014). Although resistance to erosion was not specifically quantified, bedrock above the knickpoint was found to have textural and mineralogical characteristics associated with resistance to erosion, while the bedrock below the knickpoint was found to have textural and mineralogical characteristics associated with more erodible bedrock.

Research on the engineering properties of granite consistently demonstrate that, as a bedrock's average grain size decreases, the strength of the bedrock increases (Tugrul and Zarif, 1999; Sousa, 2012). In theory, this inverse relationship is caused by the components of fine-grained bedrock being more effective at binding together. The increased cohesion in fine-grained bedrock causes the rock to be more resistant to erosion (Tugrul and Zarif, 1999). In addition, the control of grain size on rock resistance may be primarily related to grain size's influence on the porosity of bedrock, where fine-grained rocks have lower porosity than coarse rocks (Tugrul and Zarif, 1999; Lagasquie et al., 2012). Granitic rocks that have lower porosity are, in general, stronger and more resistant to erosion than granitic rocks with higher porosity (Tugrul and Zarif, 1999). Although texture is known to influence rock strength and resistance to erosion, the exact 
mechanisms of how texture influences the weathering of bedrock is unknown and continues to be an active area of research (Lagasquie et al., 2012).

In granitic rocks, quartz content is also used to roughly estimate bedrock strength because it is often the hardest mineral present (Sousa, 2012). Quartz content increases rock strength in a variety of ways. For example, quartz has a tendency to occur interstitially in granitic rocks and, as a consequence, increases the compressional and tensile strength of the granite (Tugrul and Zarif, 1999). The mineralogy can also influence the overall strength of the bedrock through being more or less resistant to weathering (Sousa, 2012). Quartz is also well known for being highly resistant to physical weathering (e.g., Tugrul and Zarif, 1999, Sklar and Deitrich, 2001; Lagasquie et al., 2012). Granites that have higher percentages of quartz are lithologically more resistant to bedrock incision by abrasion (Sklar and Deitrich, 2001; Sousa, 2012). In fact, most studies evaluating the effect of quartz content on granitic strength demonstrate that increased quartz content increases overall bedrock strength (Tugrul and Zarif, 1999; Sousa, 2012).

This study does not find any statistically significant differences between the mafic mineral content of bedrock above and below the knickpoint. One possible explanation is that abrasion is the dominant process controlling rates of incision in bedrock channels. When biotite in granite reacts with water, the biotite expands, causing the granite to rapidly disintegrate into gruss (Wahrhaftig, 1965). If chemical weathering were the dominant process driving incision in the investigated channels, there might be differences in the amount of mafic minerals in the bedrock above and below a knickpoint, similar to 
the landscape scale studies where biotite-rich materials are more frequently found at lower elevations (Lagasquie et al., 2012; Migon and Vieira, 2014).

Rates of incision are directly related to bedrock strength, where stronger bedrock erodes at slower rates than weaker bedrock (Sklar and Dietrich, 1998). Often, the gently sloped bedrock above a knickpoint is expected to be weaker than the steeply sloped bedrock below a knickpoint (e.g., Prederson and Tressler, 2012). This is because stronger bedrock is thought to require more shear stress to abrade the surface and incise at the same rate as the weaker bedrock (e.g., Prederson and Tressler, 2012); a stationary knickpoint will develop at the contact of the two rock types in the longitudinal profile (Prederson and Tressler, 2012). In heterogeneous granitic landscapes, variations in rock hardness cause individual rock units to erode at different rates (Lagasquie et al., 2012); however, the bedrock above the knickpoint is often texturally or mineralogically more resistant than the bedrock below the knickpoint (Lagasquie et al., 2012; Migon and Vieira, 2014). Bedrock that is quartz-rich and finer-grained is more resistant to physical erosion, causing that bedrock to erode more slowly than material with lower quartz content and coarser grain sizes (Godard, 1965; Flageollet, 1977; Peulvast, 1985b, in Lagasquie et al., 2012; Migon and Vieira, 2014). Bedrock that is resistant to erosion is more frequently found at higher elevations while the weaker bedrock is more frequently present at lower elevations (Lagasquie et al., 2012; Migon and Vieira, 2014). In granitic bedrock channels that flow over both weak and resistant rock types, a stationary knickpoint can develop at the lithologic contact anchored by the resistant rock type (Lagasquie et al., 2012; Migon and Vieira, 2014). The knickpoint is formed because the 
weaker material can be incised at a faster rate than the more resistant bedrock (Lagasquie et al., 2012; Migon and Vieira, 2014). For example, the bedrock above the knickpoints in Yosemite Valley's Wildcat Creek (Fig. 4-A) has more quartz and is finer-grained. The more resistant granite in Wildcat Creek could be eroding at a slower pace than the material below the knickpoint, and over time, developed a large, stationary knickpoint anchored by the finer-grained, quartz-rich bedrock.

While knickpoints occur frequently at lithologic transitions in the Sierra Nevada, there are still many observable knickpoints within single mapped geologic units. The only tributaries that could be safely accessed to sample the bedrock above and below knickpoints were from channel segments underlain by single lithologic units (Figs. 4, 5). Of those samples where the bedrock above and below the knickpoint was analyzed, only Yosemite Valley's Tamarack Creek had slightly coarser bedrock grain size above the knickpoint by roughly 0.2 grains/cm (Fig. 4-C). The bedrock at higher elevations above the knickpoint had as twice as much quartz than the bedrock below the knickpoint which may override the coarse-grain size in controlling erodibility in this instance. Although Tamarack Creek only flows over the El Capitan Granite, there are statistically significant grain size and mineralogical variations within that individual lithologic unit. Mineralogical and grain size variation above and below the knickpoint within individual lithologic units was found in every bedrock unit sampled (Figs. 4, 5).

Bedrock samples from individual geologic units above and below channel knickpoints demonstrate that geologic maps fail to capture the textural or mineralogical variation expressed within a rock unit. By sampling the bedrock above and below 
bedrock channel knickpoints, this study was able to capture and quantify the variation within a single geologic unit that potentially predisposes a channel to form a knickpoint. The results provide sufficient evidence to argue that a channel's underlying lithology can influence channel form, and the textural and mineralogical characteristics controlling differences in rock strength can produce substantial knickpoints over time.

Sierra Nevada knickpoints are not necessarily signals of tectonic activity, but are often a consequence of lithologic heterogeneity where the weaker bedrock is eroded at a faster rate than the more resistant bedrock. In a manner consistent with results from structural geomorphic studies, results from this study refute the idea that all bedrock channel knickpoints are related to pulses of uplift by providing evidence that channel gradients can be controlled by mineralogy and grain size of a channels underlying bedrock (e.g., Lagasquie et al., 2012; Migon and Vieira, 2014). Studies in the Sierra Nevada that use bedrock channel knickpoints as evidence for tectonic activity without explicitly defining the local relationship between channel slope and the underlying lithology are inconclusive (Matthes, 1930; Wakabayashi and Sawyer, 2001; Clark et al., 2005; Figueroa and Knott, 2010; Wakabayashi, 2013).

\section{CONCLUSION}

In granitic landscapes across the globe, channel incision is influenced by rock strength, and the bedrock strength is partially controlled by its texture and mineralogy. Different rates of erosion can cause large knickpoints in bedrock channels over time. This study targets bedrock channel knickpoints in the Sierra Nevada to understand how 
heterogeneous bedrock influences channel morphology. The plutonic bedrock samples taken above and below channel knickpoints from the North Fork Feather and Merced river tributaries indicate that bedrock above knickpoints has finer average grain sizes and higher percentages of quartz: both characteristics of stronger granitic rock. The bedrock below knickpoints is coarser and contains less quartz: characteristic of weaker granitic rock. When the lithologic variation typical of the Sierra Nevada is accounted for, the underlying assumption that bedrock channel knickpoints are transient features responding to rapid pulses of uplift is found to be incorrect. Although this study did not explicitly quantify the bedrock hardness above and below the knickpoints, the data increase the current understanding of how bedrock channel form is affected by the modal mineralogy and grain size of a rock. The data show that mineralogy and grain size have a statistically significant control on the rate and form of landscape development in the Sierra Nevada, and granitic bedrock channel knickpoints are capable of forming in the absence of upliftdriven incision. 


\section{REFERENCES CITED}

Allen, G. H., Barnes, J. B., Pavelsky, T. M., and Kirby, E., 2013, Lithologic and tectonic controls on bedrock channel form at the northwest Himalayan Front: Journal of Geophysical Research: Earth Surface, v. 118, p. 1806-1825.

Bateman, P. C., and Wahrhaftig, C., 1966, Geology of Northern California: California Division of Mines and Geology Bulletin 190, p. 150-192

Cassel, E. J., and Graham, S. A., 2011, Paleovalley morphology and fluvial system evolution of Eocene-Oligocene sediments ("auriferous gravels"), Northern Sierra Nevada, California: implications for climate, tectonics and topography: Geological Society of America Bulletin v. 123, p. 1699-719.

Cecil, M. R., Reiners, P. W., and Chase, C. G., 2010, Cenozoic exhumation of the northern Sierra Nevada, California, from (U-Th)/He thermochronology: Geological Society of America Bulletin, v. 118, p. 1481 - 1488.

Clark, M. K., Maheo, G., Saleeby, J., and Farley, K. A., 2005, The nonequilibrium landscape of the southern Sierra Nevada, California: Geological Society of America Today, v. 9, no. 9, p. 4-10.

Calkins, F. C. Bedrock geologic map of Yosemite Valley, Yosemite National Park, California: 1: 24000. Map. Reston, VA: US Geological Survey, 1985. Map I-1639.

Crosby, B., and Whipple, K., 2006, Knickpoint initiation and distribution within fluvial networks: 236 waterfalls in the Waipaoa River, North Island, New Zealand: Geomorphology, v. 82, p. 16-38.

Figueroa, A. M., and Knott J. R., 2010, Tectonic geomorphology of the southern Sierra Nevada Mountains (California): Evidence for uplift and basin formation: Geomorphology, v. 123, p. 34-45.

Gabet, E., 2013, Late Cenozoic uplift of the Sierra Nevada, California: A critical analysis of the geomorphic evidence: American Journal of Science, v. 314, p. 1224-1257, doi 10.2475/08.2014.03.

Gabet, E., 2013, Instructions for extracting channel profiles with Whitebox and Profiler Tool, (available at http://geosun.sjsu.edu/ mgabet/Goodies/Goodies.html)

Gilbert, G. K., 1877, Report on the geology of the Henry Mountains: U.S. Geologic Survey Unnumbered Series, Geographical and geological survey of the Rocky Mountain region: Washington, D.C., Government Printing Office, 106 p. 
Harden, J. W., 1987, Soils developed in granitic alluvium near Merced, California: U.S. Geologic Survey Bulletin 1590 A, 76 p., http://pubs.er.usgs.gov/publication/b1590A.

Howard, A. D., 1998, Long profile development of bedrock channels:

Interaction of weathering, mass wasting, bed erosion, and sediment transport, in Rivers Over Rock: Fluvial Processes in Bedrock Channels: Geophysical Monograph, v. 107.

Huang, G., Kadir, T., and Chung, F., 2012, Hydrological response to climate warming: The upper Feather River watershed: Journal of Hydrology, p.138-50.

Kaplan-Henry, T. and Courtier, J., 2012, Giant Sequoia National Monument hydrology report: US Forest Service. 251 p., http://www.fs.fed.us/r5/sequoia/gsnm/deis/HydrologyReport.pdf.

Lagasquie, J. J., Laget, Y., and Godard, A., 2012, Rock resistance and its influence on landforms in basement terrains, in Godard, A., Lagasquie, J. J., and Laget, Y., 2012, Basement Regions, Springer Paris 306, p. 93-116.

Matthes, F. E., 1930, Geologic history of the Yosemite Valley: U.S. Geological Survey Professional Paper v. 160, 137 p.

Migon, P., and Vieira, G., 2014, Granite geomorphology and its geological controls, Serra da Estrela: Geomorphology, v. 226, p. 1-14.

National Elevation Dataset: U.S. Geological Survey (Available at http://nationalmap.gov/viewer.html).

Pederson, J. L., and Tressler, C., 2012, Colorado River long-profile metrics, knickzones and their meaning: Earth and Planetary Science Letters, v. 345 - 348, p. 171-179.

Poage, M. A., and Chamberlain, C. P., 2002, Stable isotope evidence for a Pre-middle Miocene rain shadow in the western Basin and Range: Implications for the paleotopography of the Sierra Nevada: Tectonics, v. 21, doi: 10.1029/2001TC001303.

Sklar, L. S., and Dietrich, W. E., 2001, Sediment and rock strength controls on river incision into bedrock: Geology, v. 29, p.1087-1090.

Sousa, L. M. O., 2012, The influence of the characteristics of quartz and mineral deterioration on the strength of granitic dimensional stones: 
Environmental Earth Science, v. 69, p. 1333-1346, doi: 10.1007/s12665-0122036-x

Stock, J. D., and Montgomery, D. R., 1999, Geologic constraints on bedrock river incision using the stream power law: Journal of Geophysical Research, v. 104, p. 4983-4993.

Tugrul, A., and Zarif, I. H., 1999, The correlation of mineralogical and textural characteristics with engineering properties of selected granitic rocks from Turkey: Engineering Geology, v. 51, p. 303-317, doi: doi:10.1016/S00137952(98)00071-4

Wahrhaftig, C., 1965, Stepped topography of the Southern Sierra Nevada, California: Geological Society of America Bulletin, v.76, p. 1165-1190.

Wakabayashi, J., and Sawyer, T.L., 2001, Stream incision, tectonics, uplift, and evolution of topography of the Sierra Nevada, California: The Journal of Geology, v. 109, p. 539-562.

Wakabayashi, J., 2013, Paleochannels, stream incision, erosion, topographic evolution, and alternative explanations of paleoaltimetry, Sierra Nevada, California: Geosphere, v. 9, p. 191-215, doi:10.1130/GES00814.1

Walsh, L. S., Martin, A. J., Ojha, T. P., and Fedenczuk, T., 2012, Correlations of fluvial knickzones with landslide dams, lithologic contacts, and faults in the Southwestern Annapurna Range, Central Nepalese Himalaya: Journal of Geophysical Research, v. 117, 24 p., doi:10.1029/2011JF001984.

Whipple, K. X., 2004, Bedrock rivers and the geomorphology of active orogens: Annual Review of Earth and Planetary Sciences, v. 32, p 151-185. 
APPENDIX 1.

Appendix 1-A through 1-J depict the Merced River tributary profiles and the underlying geology. The location of each profile can be found on Figure 2. Appendix 1-K is the legend for the underlying geology.

APPENDIX 1-A.

Merced River: Ribbon Falls

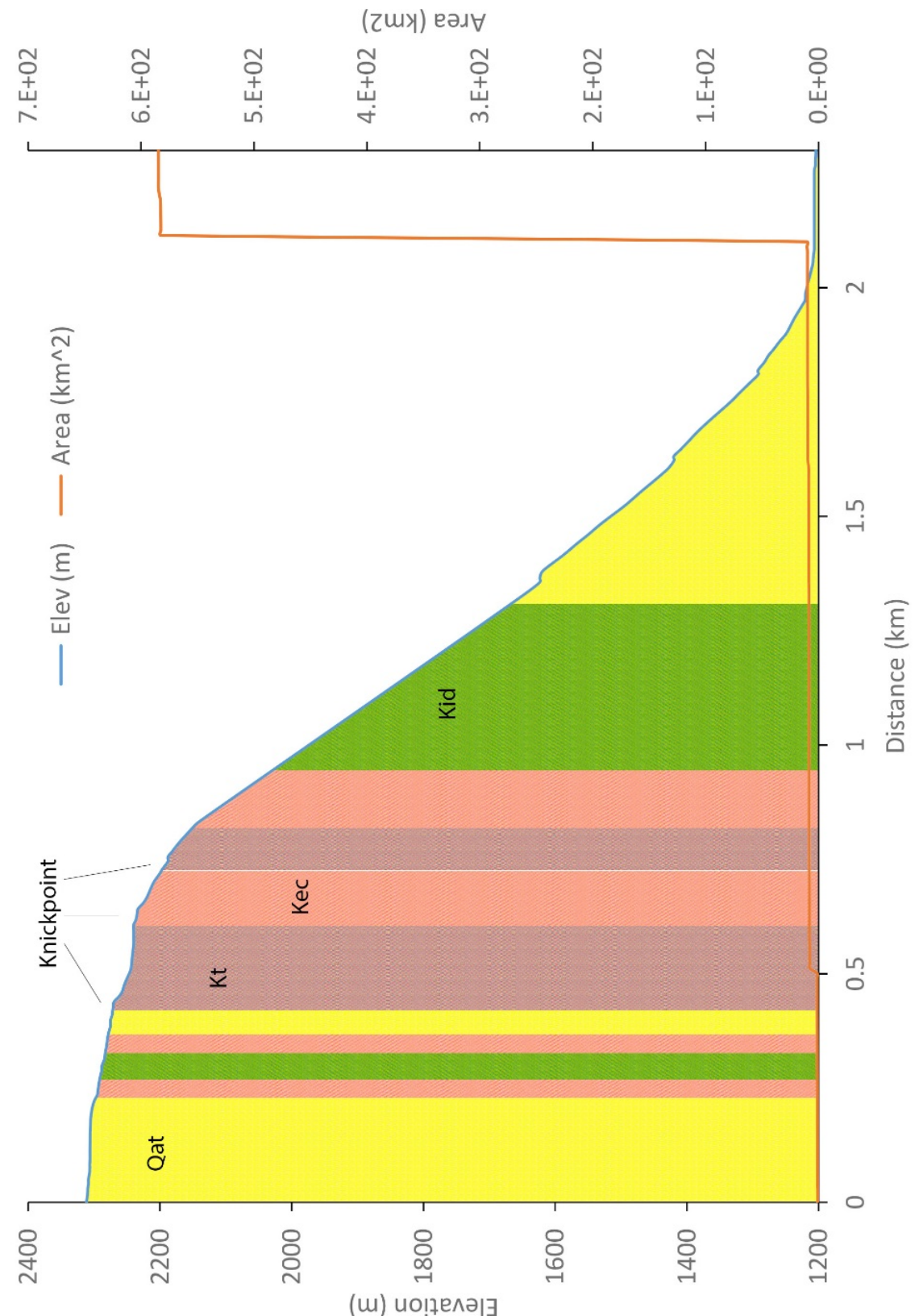


APPENDIX 1-B. Merced River: Indian Canyon Creek

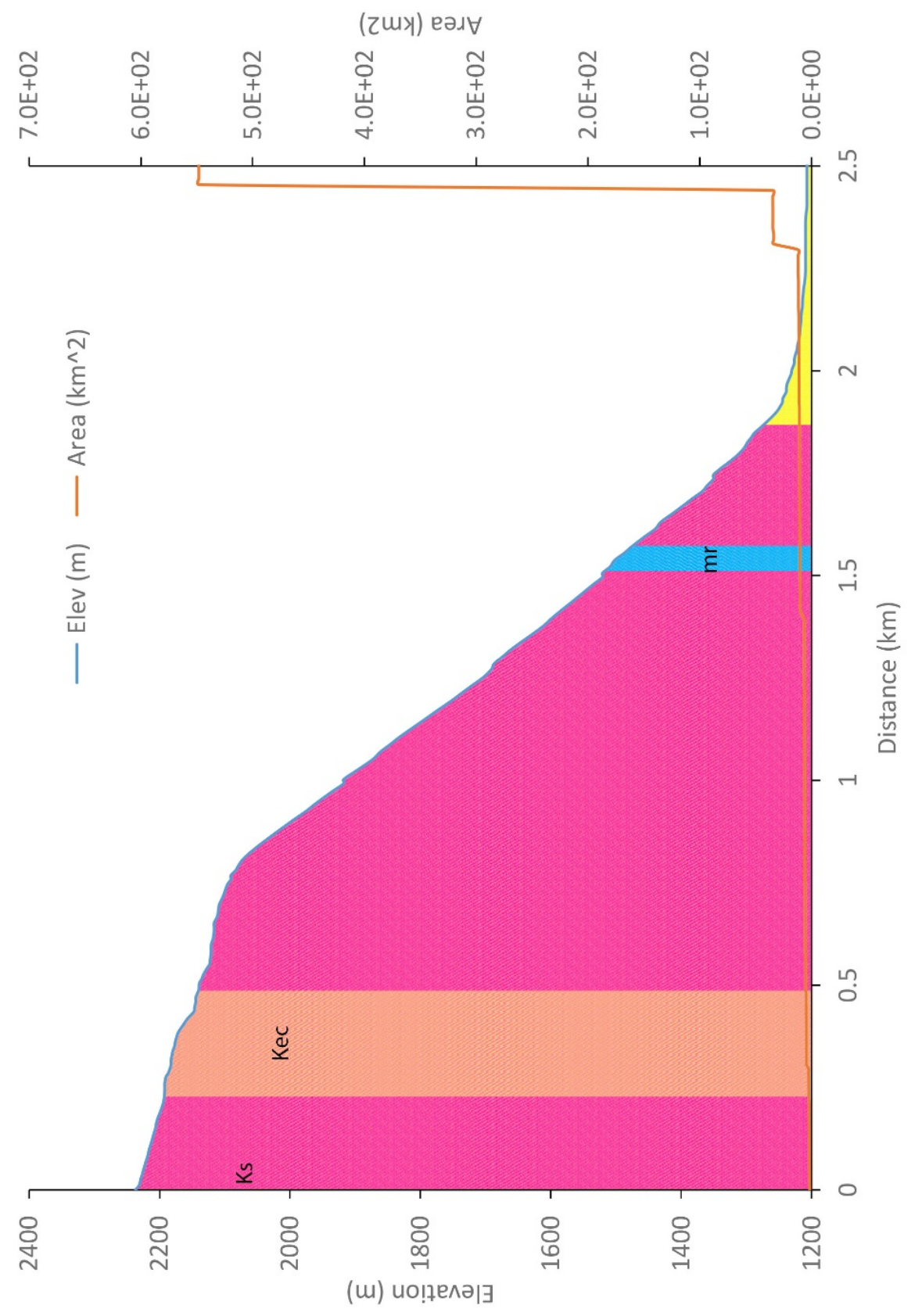


APPENDIX 1-C. Merced River: Eagle Creek

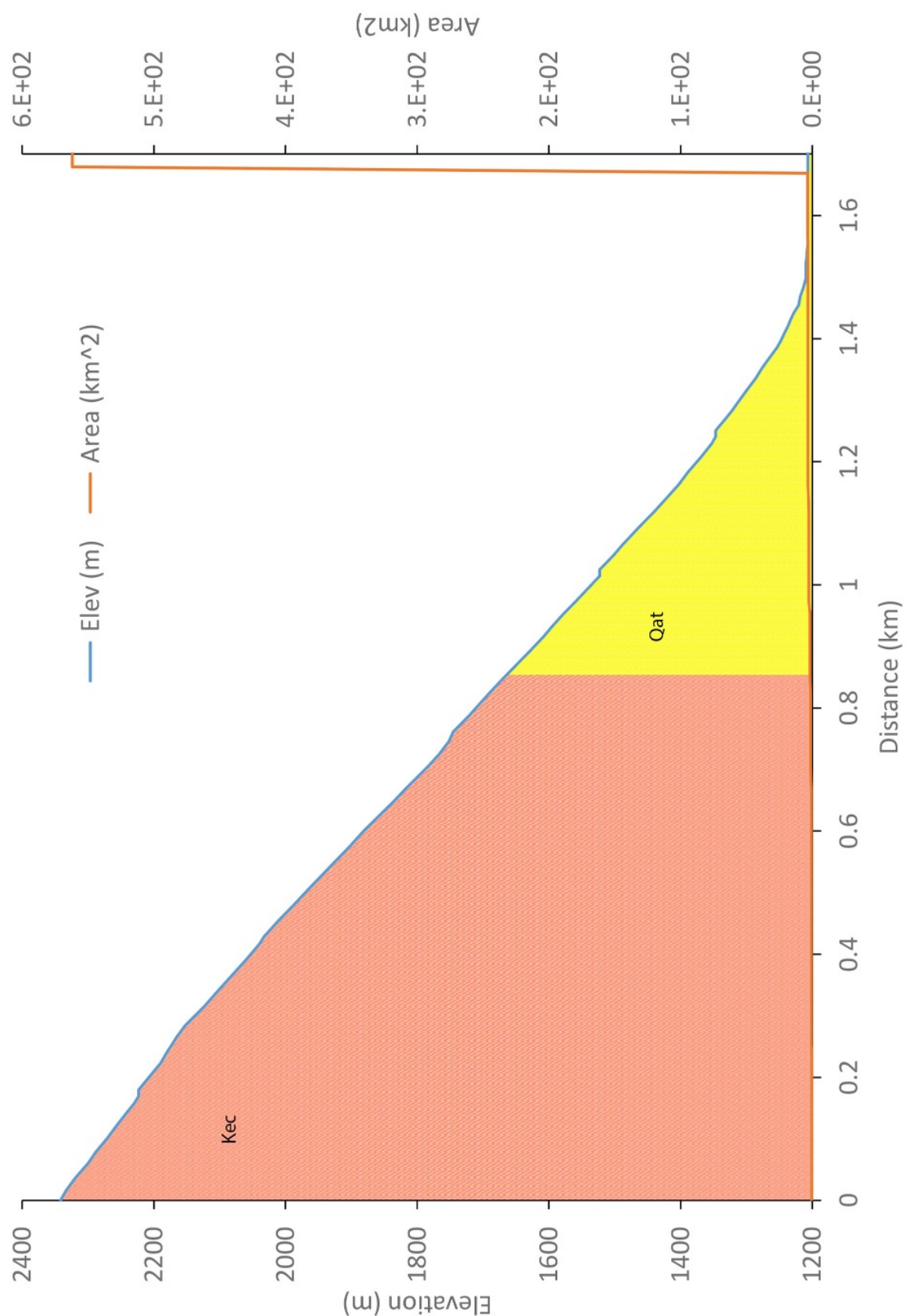


APPENDIX 1-D. Merced River: Cascade Cliffs

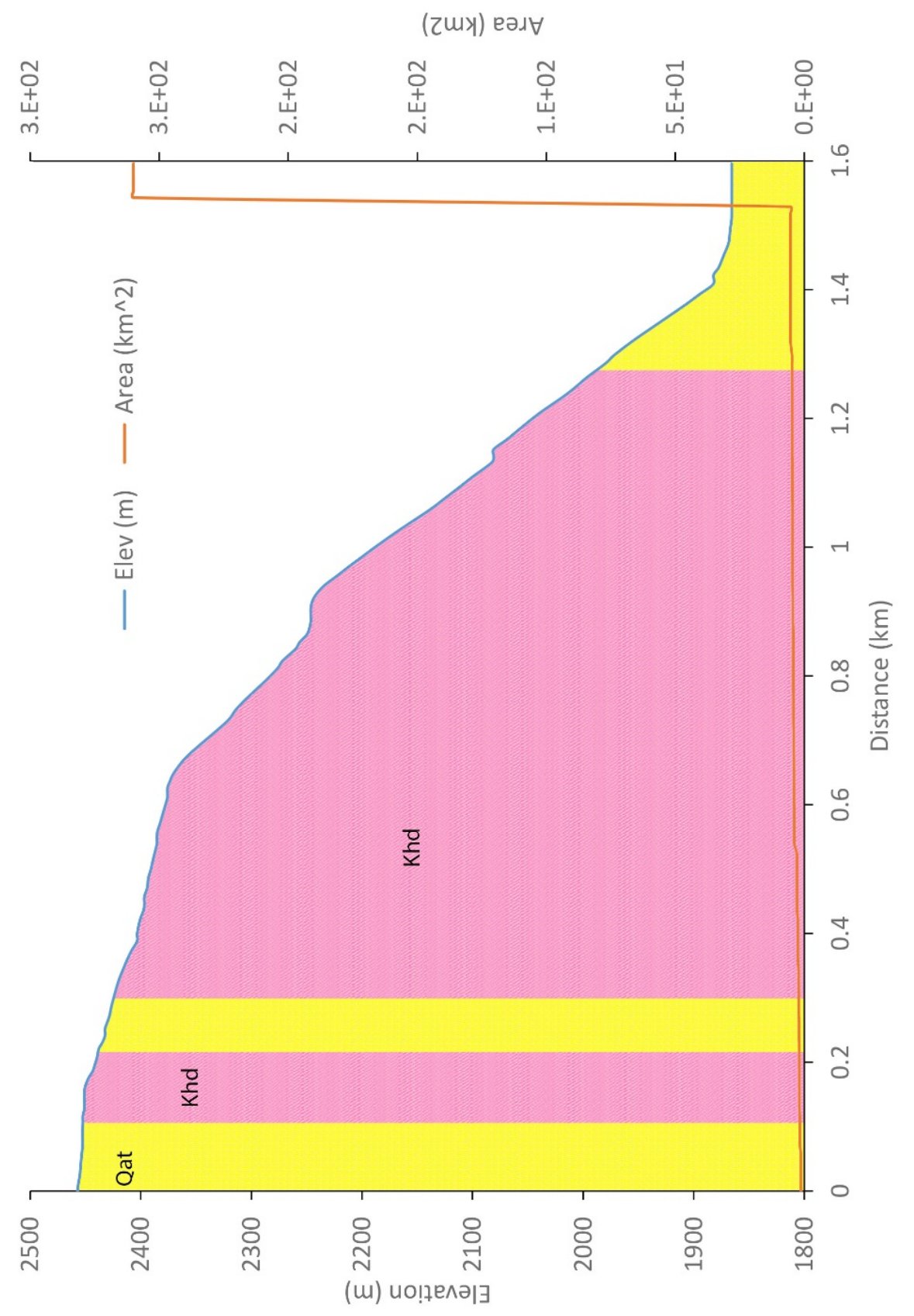


APPENDIX 1-E. Merced River: Meadow Brook to Washburn Slide

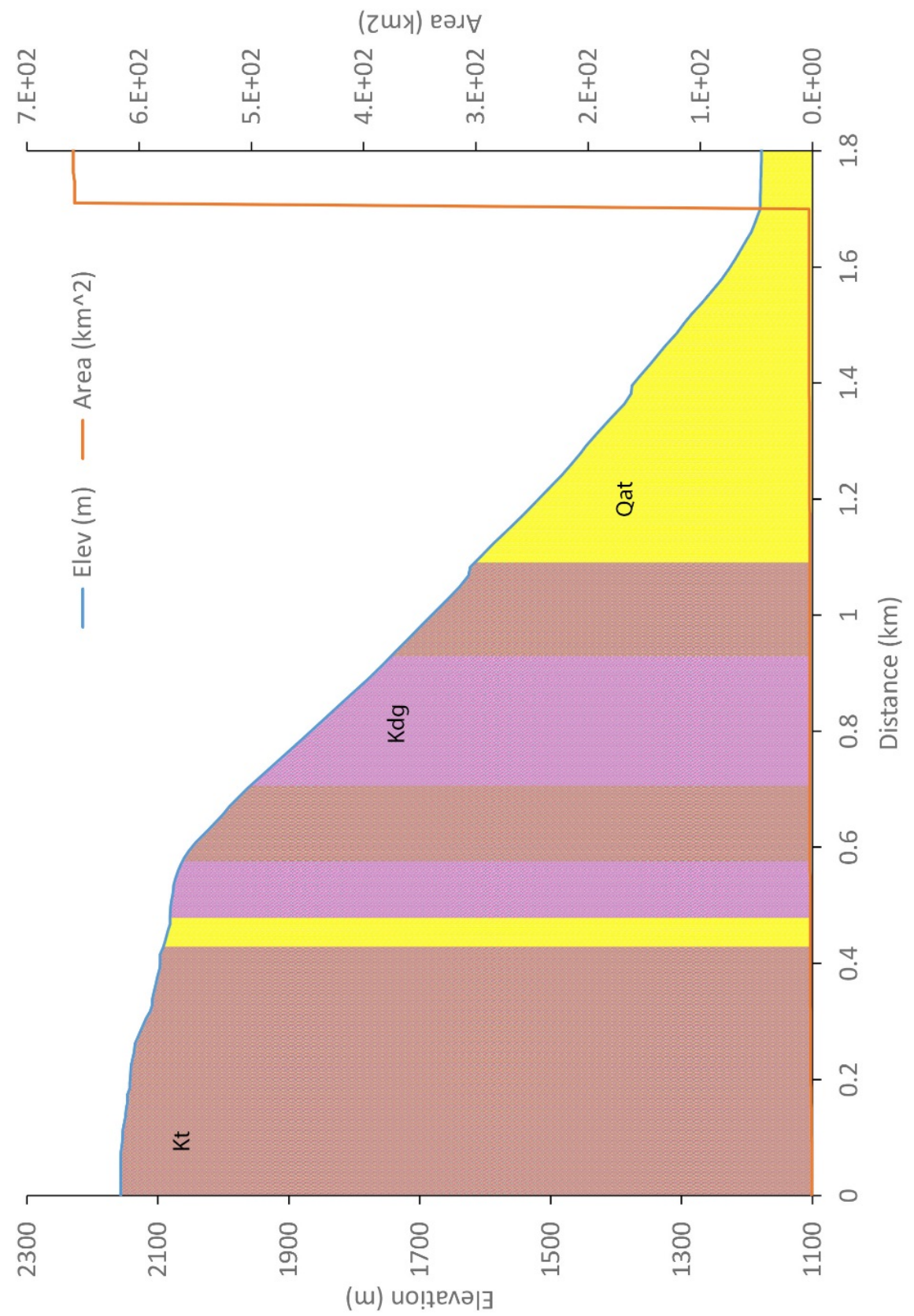


APPENDIX 1-F. Merced River: Lehamite Creek

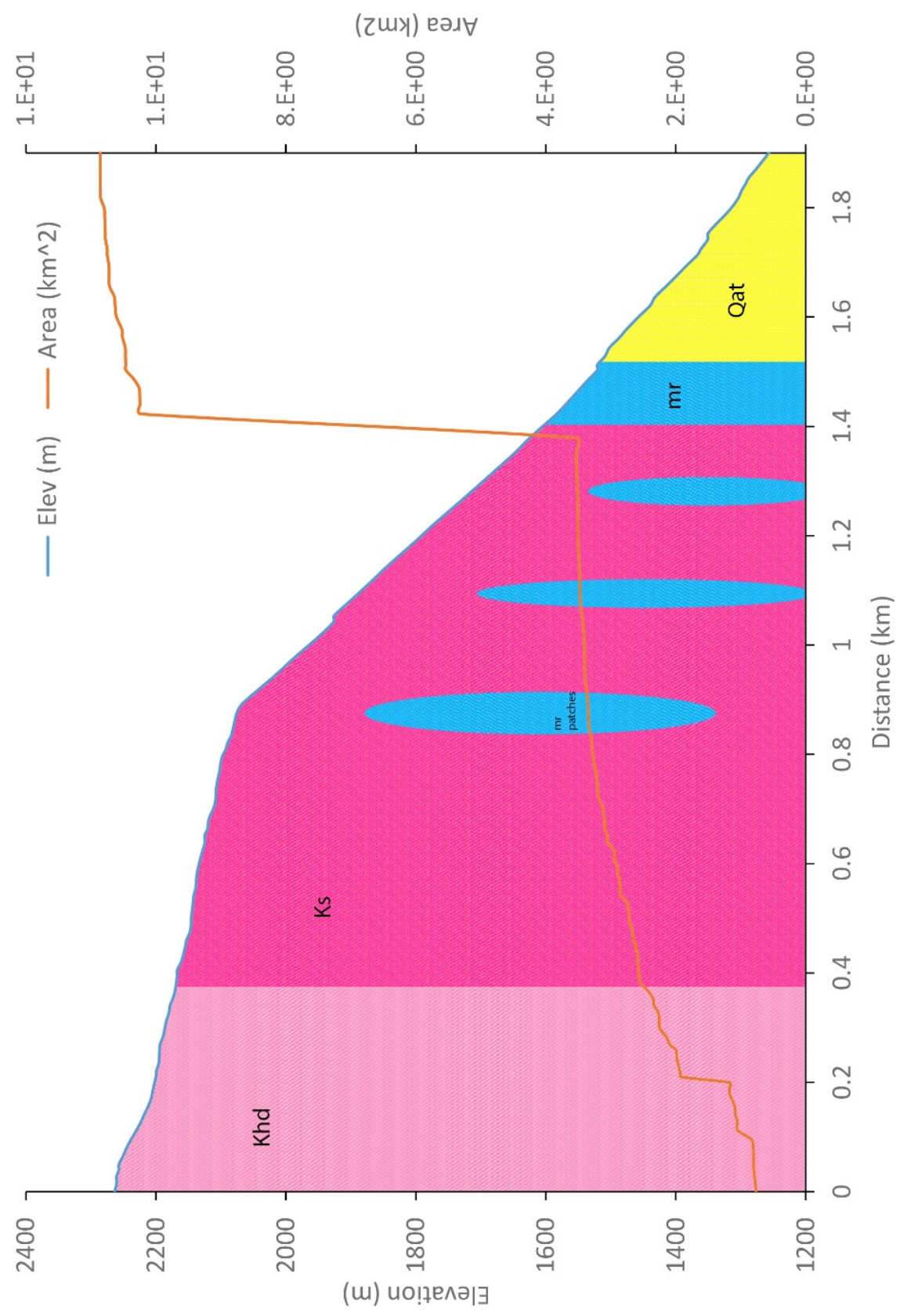


APPENDIX 1-G. Merced River: Tributary of Illilouette Creek

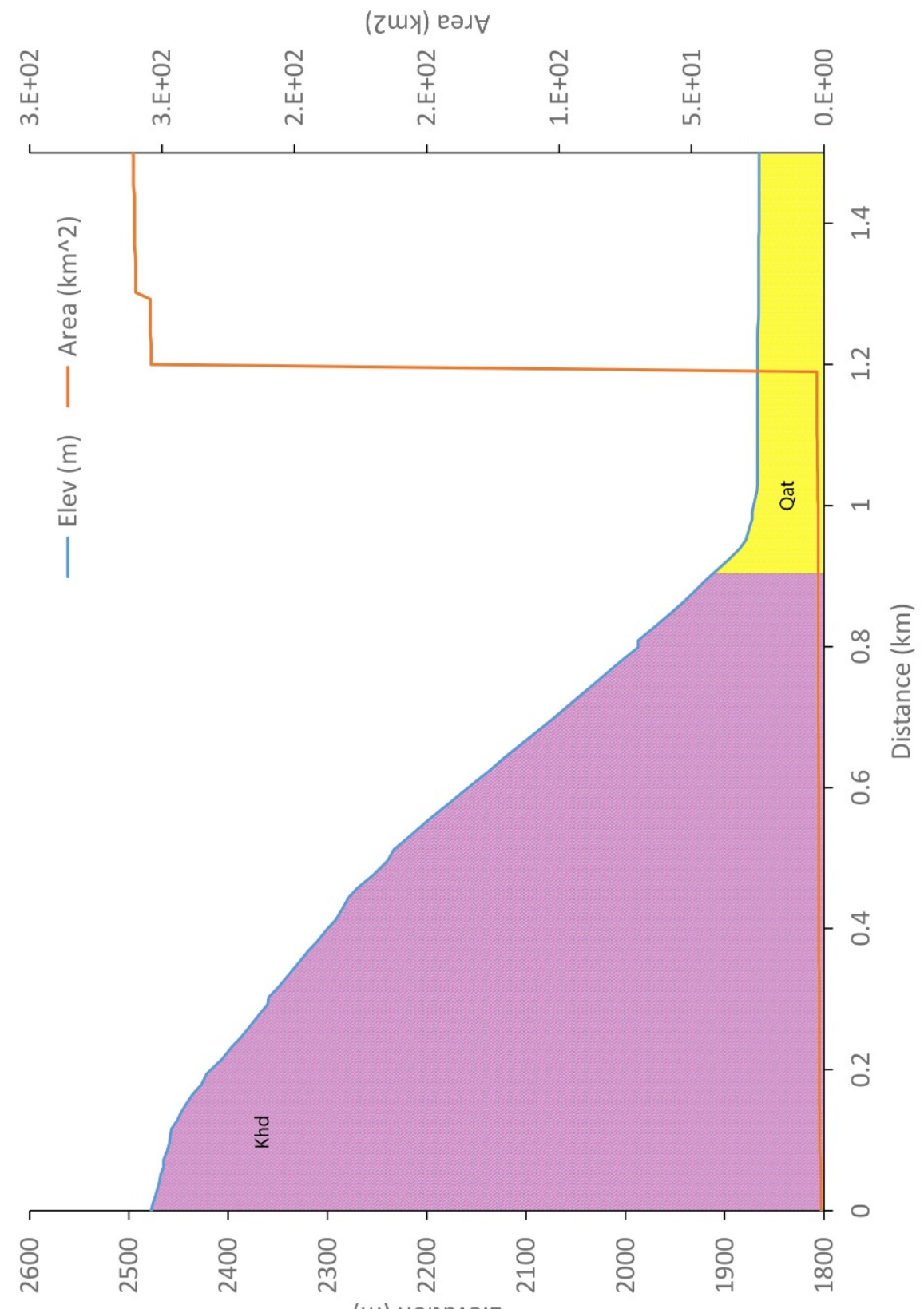

(w) นо!ฺе^키 
APPENDIX 1-H. Merced River: Rainbow View

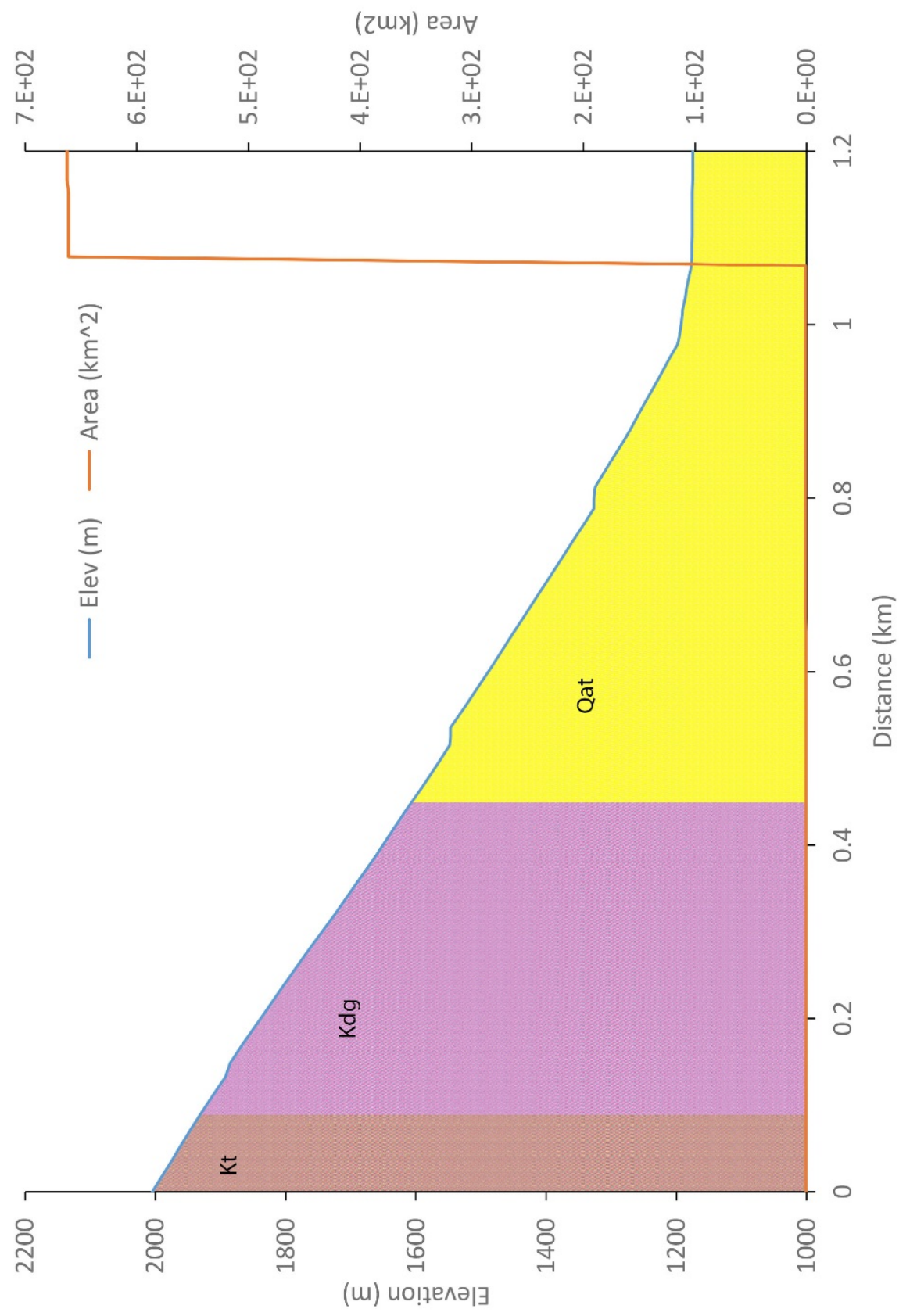


APPENDIX 1-I. Merced River: Bridalveil Creek

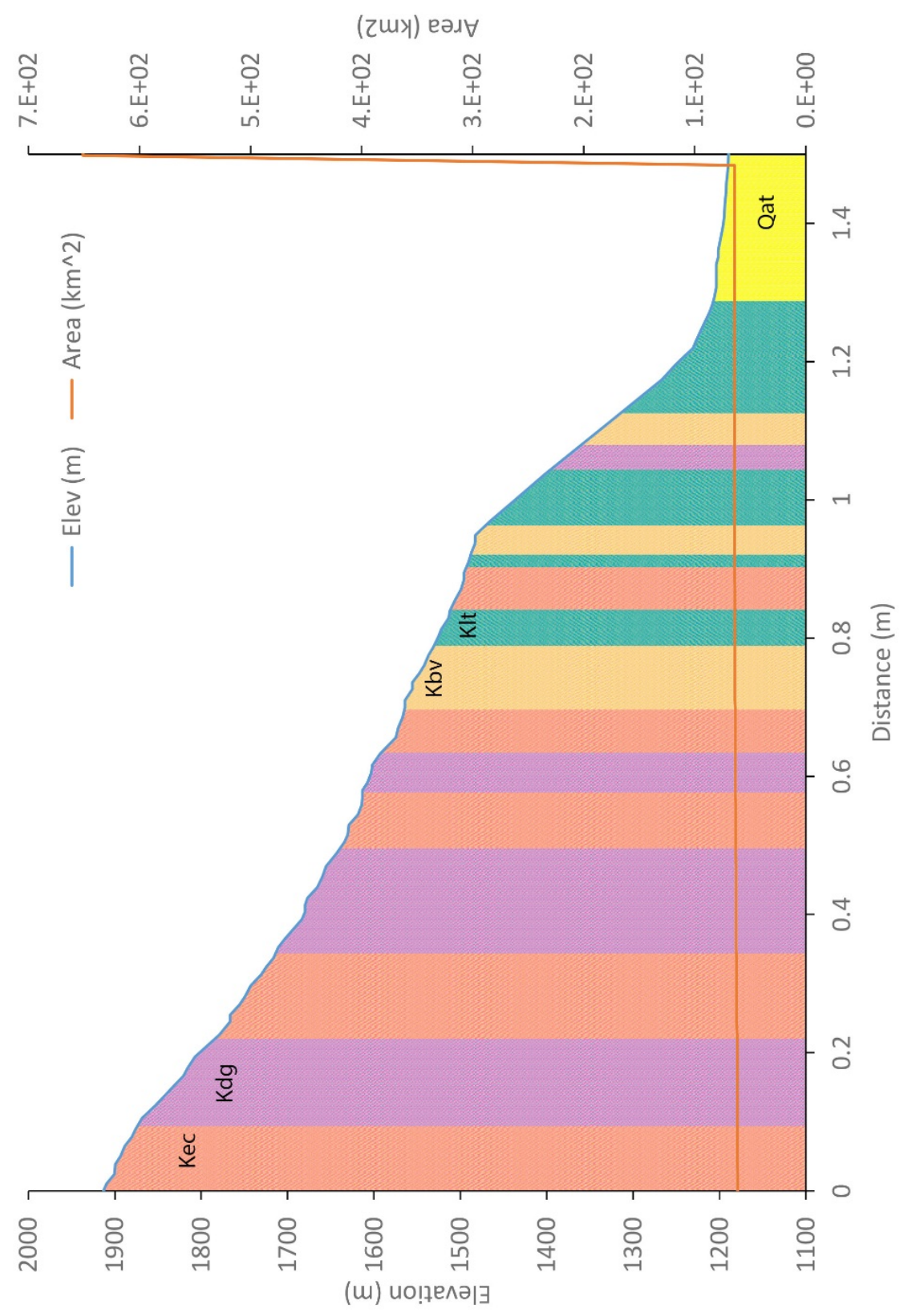


APPENDIX 1-J. Merced River: Sunrise Creek

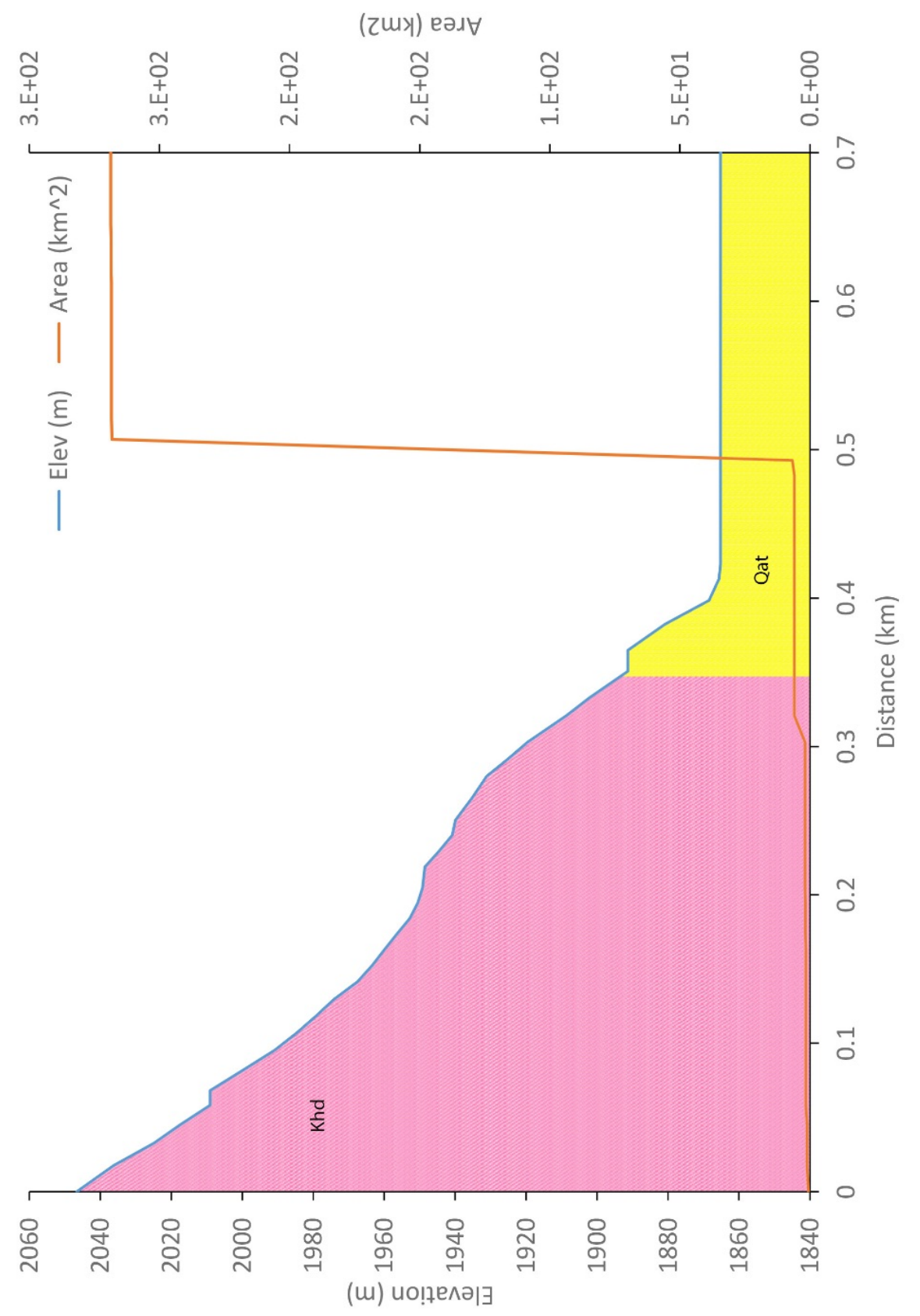


APPENDIX 1-K. Merced River: Unnamed tributary number 20

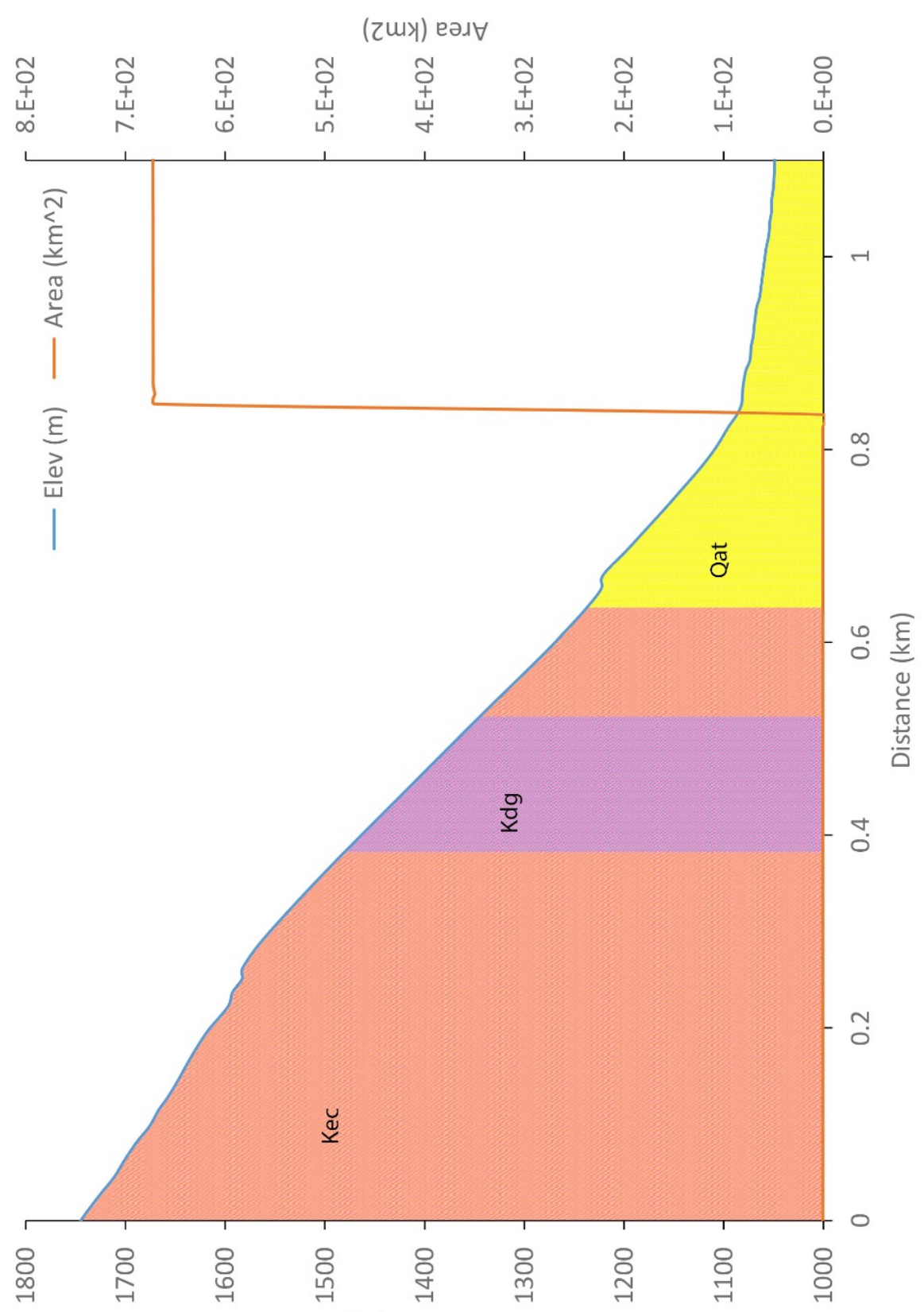

(w) ио!ฺел키 
APPENDIX 1-L. Merced River: Yosemite Creek

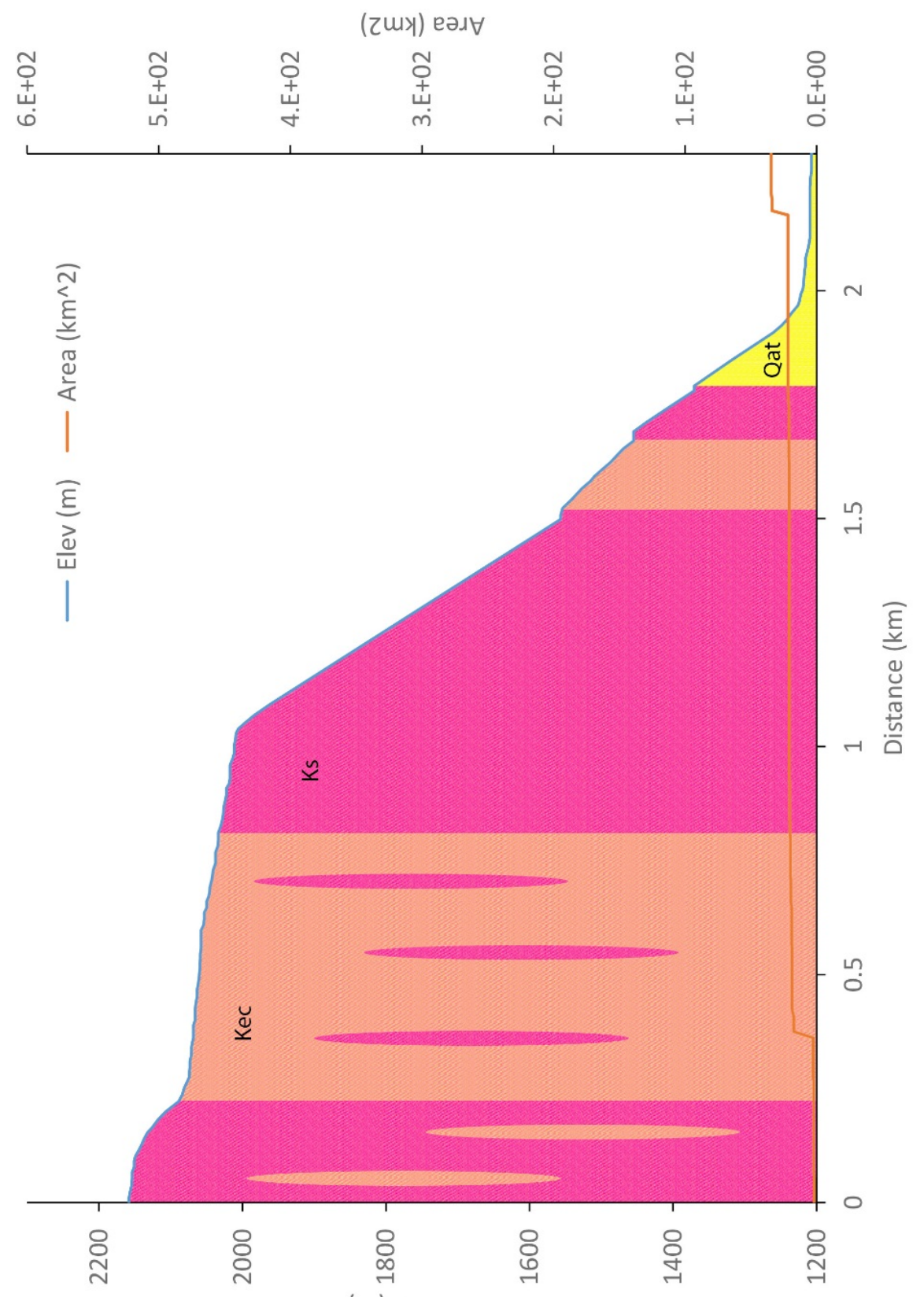

(u) บ!าะ^리 
APPENDIX 1-M. Merced River: Sentinel Creek

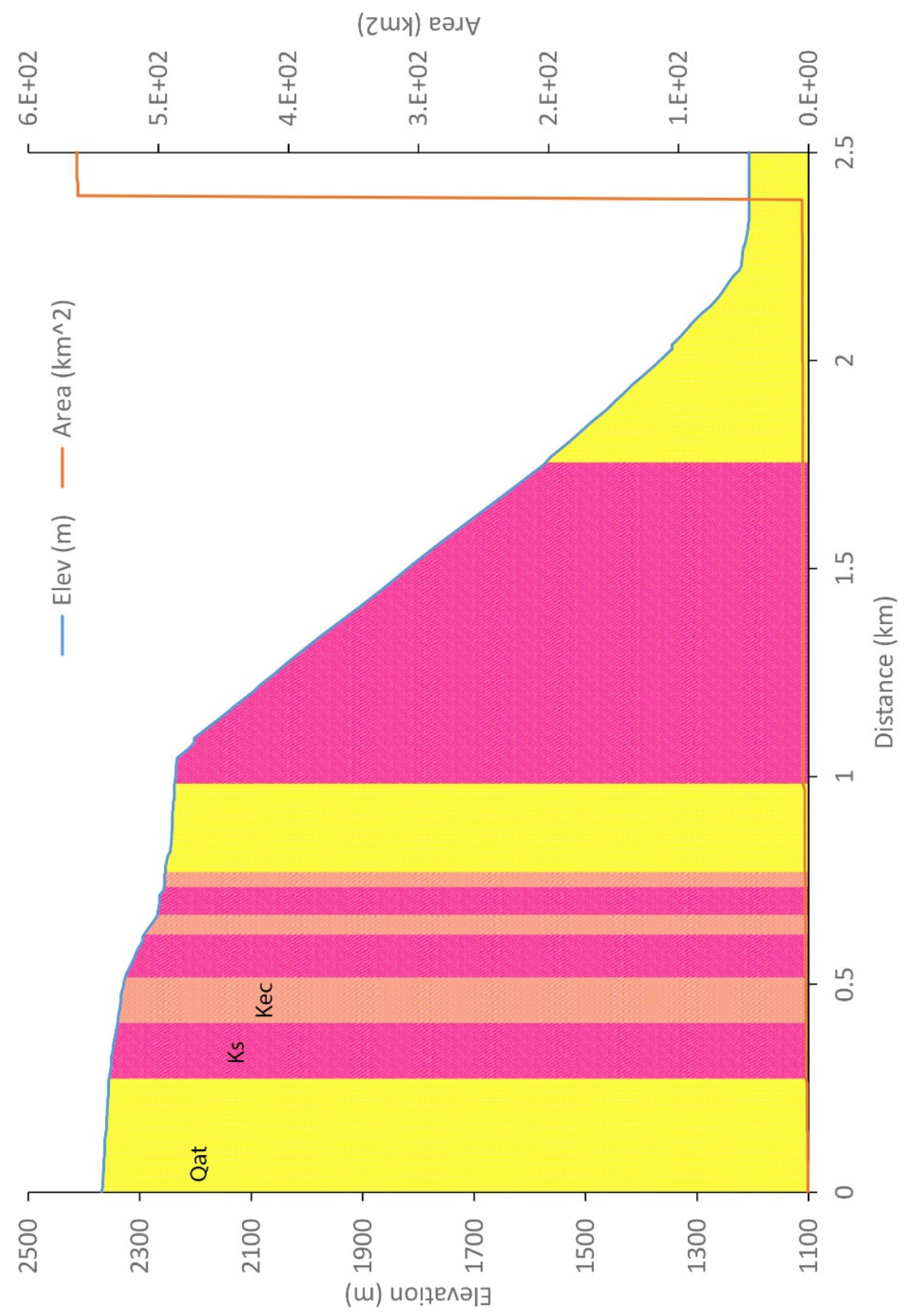


APPENDIX 1-K. Merced River: Legend

Qat Alluvium and Tallus (Quaternary)

Leaning Tower Granodiorite (Cretaceous)

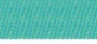

Kdg Diorite of the Rockslides (Cretaceous)

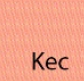

El Capitan Granite (Cretaceous)

$\mathrm{Kg}$

Tonalite of the Gateway (Cretaceous)

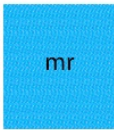

Metamorphic Rocks (Pre-Cretaceous)

Taft Granite (Cretaceous)

Kt

Ks

Sentinel Granodiorite (Cretaceous)

Kid

Diorite (Cretaceous)

Kbv

Bridalveil Granodiorite (Cretaceous) 
APPENDIX 2.

Appendix 2-A through 2-F depicts the North Fork Feather River tributary profiles and the underlying geology. The location of each profile can be found on Figure 3. Appendix 2-G is the legend for the underlying geology.

APPENDIX 2-A. North Fork of the Feather River: Heinz Creek

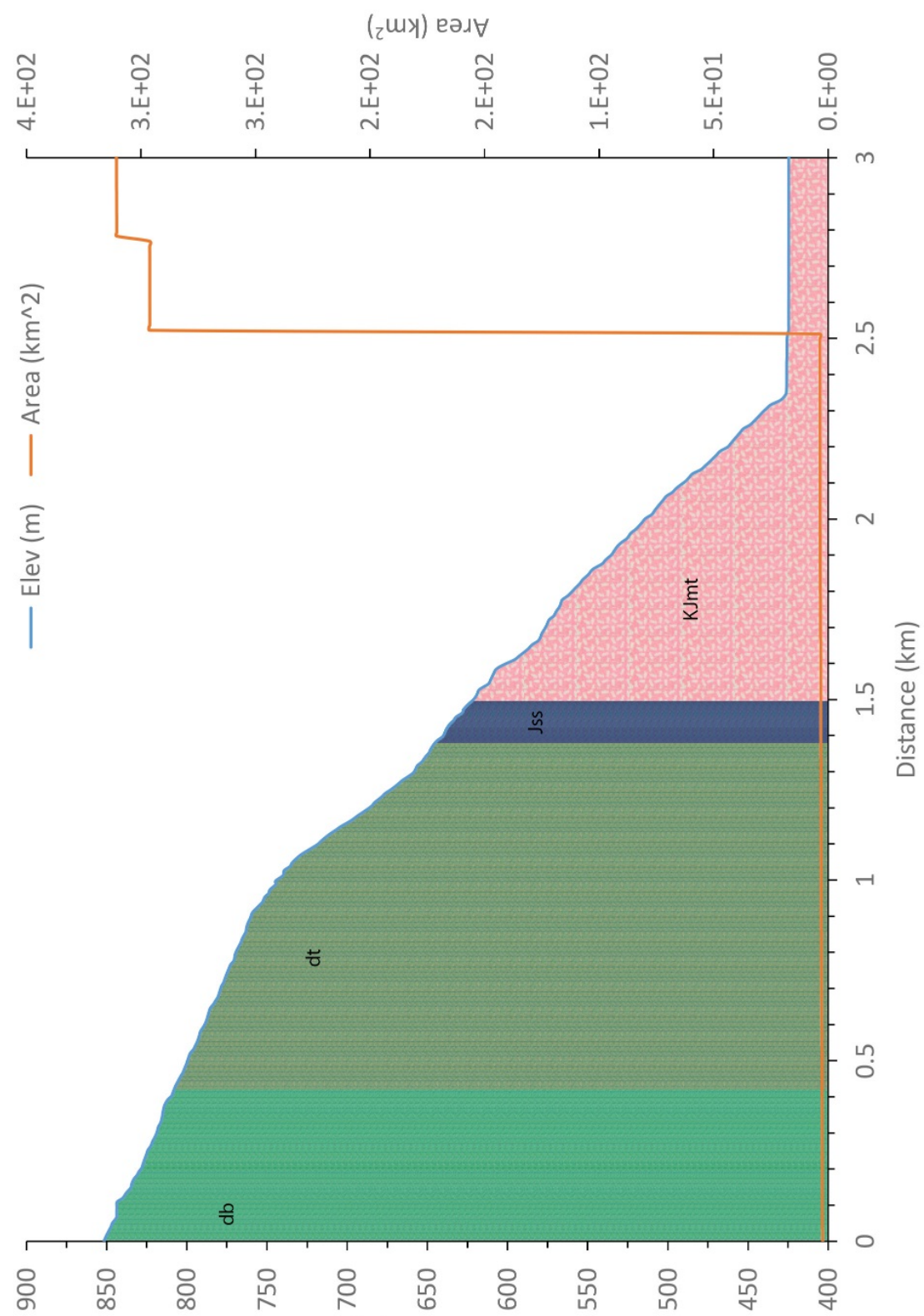

(u) ио!ฺе^әуコ 
APPENDIX 2-B. North Fork of the Feather River: Dogwood Creek

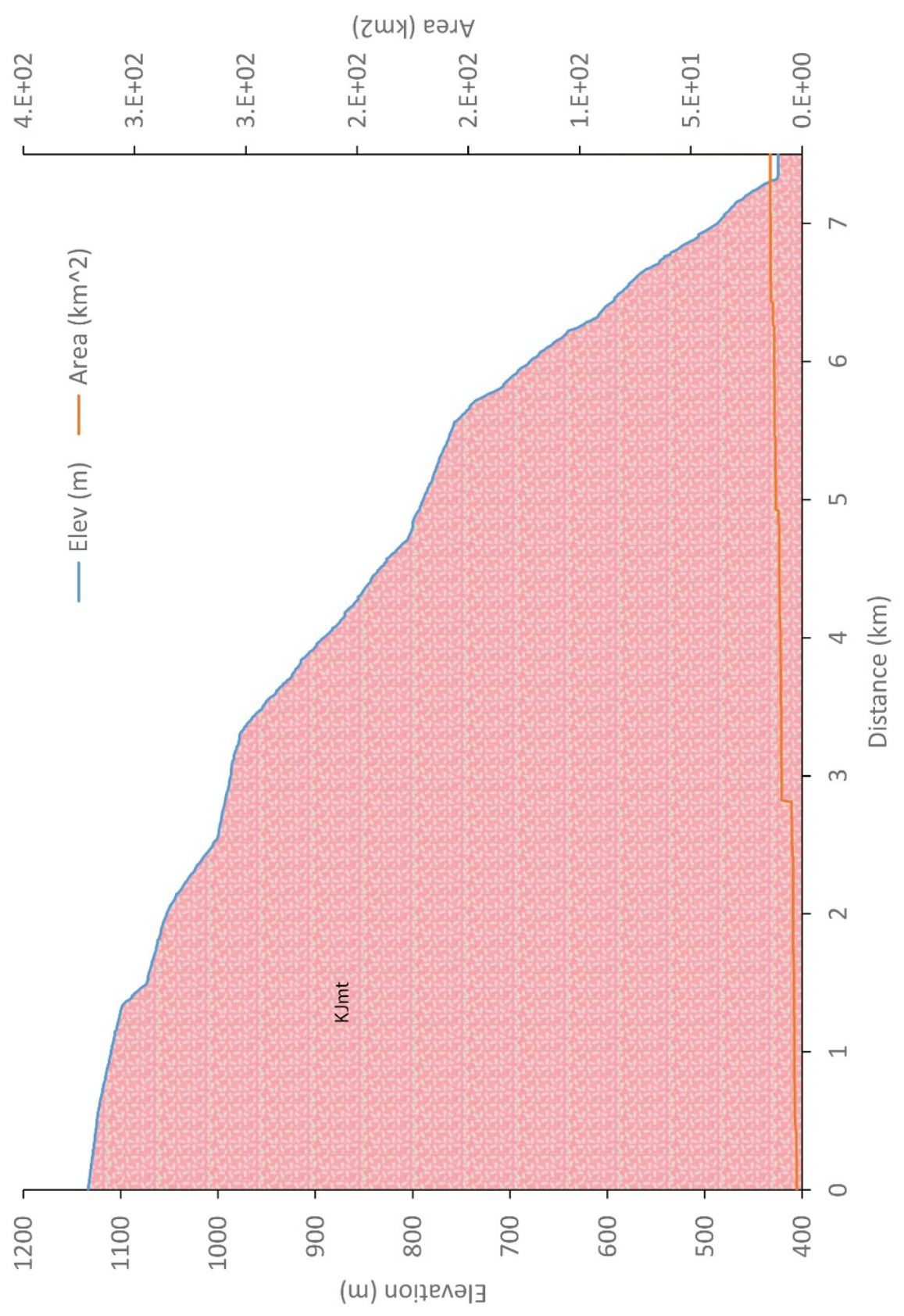


APPENDIX 2-C. North Fork of the Feather River: Tributary number 20

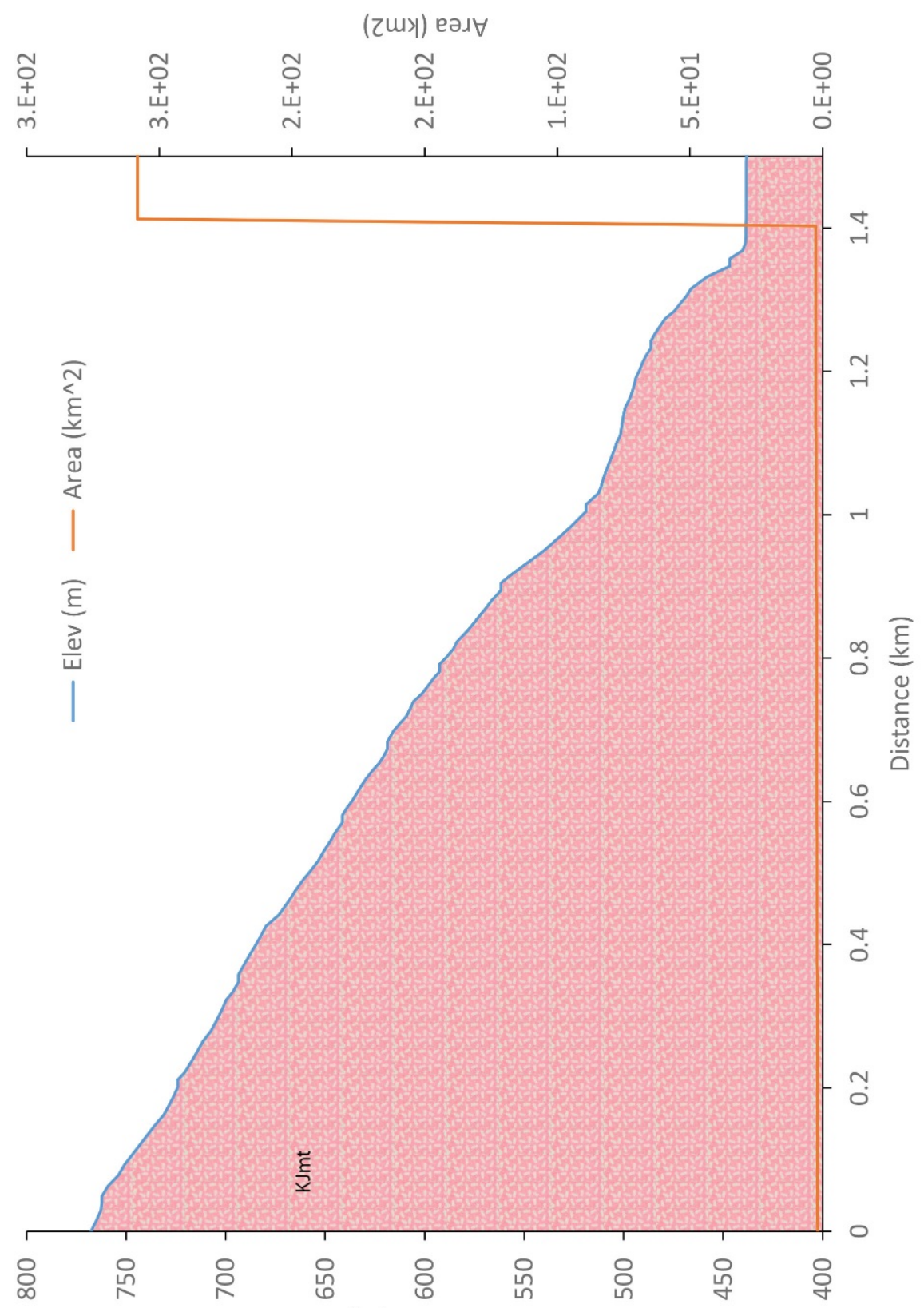

(w) ио!ฺел리 
APPENDIX 2-D. North Fork of the Feather River: Swamp Creek

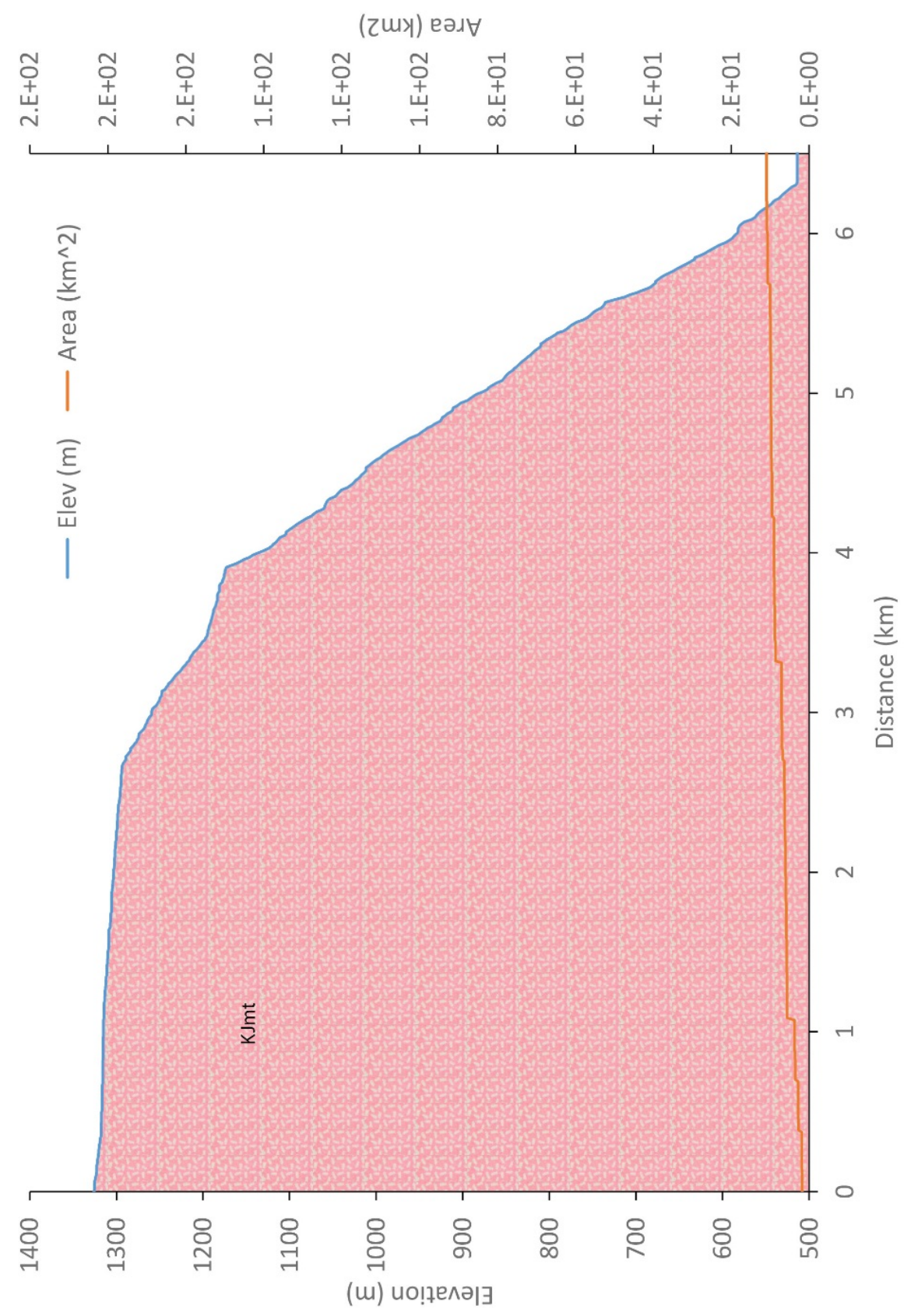


APPENDIX 2-E. North Fork Feather River: Rock Creek

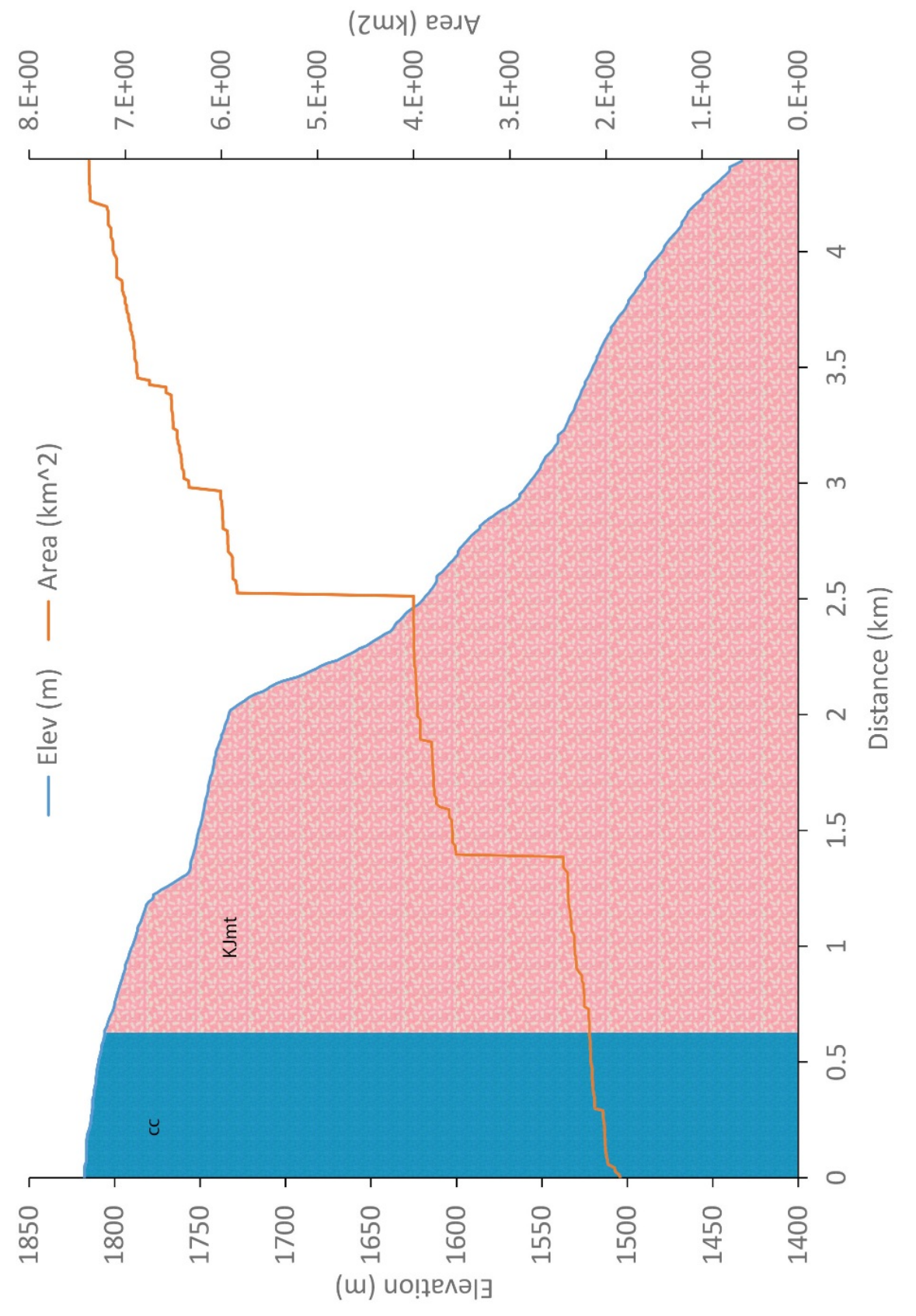


APPENDIX 2-F. North Fork Feather River

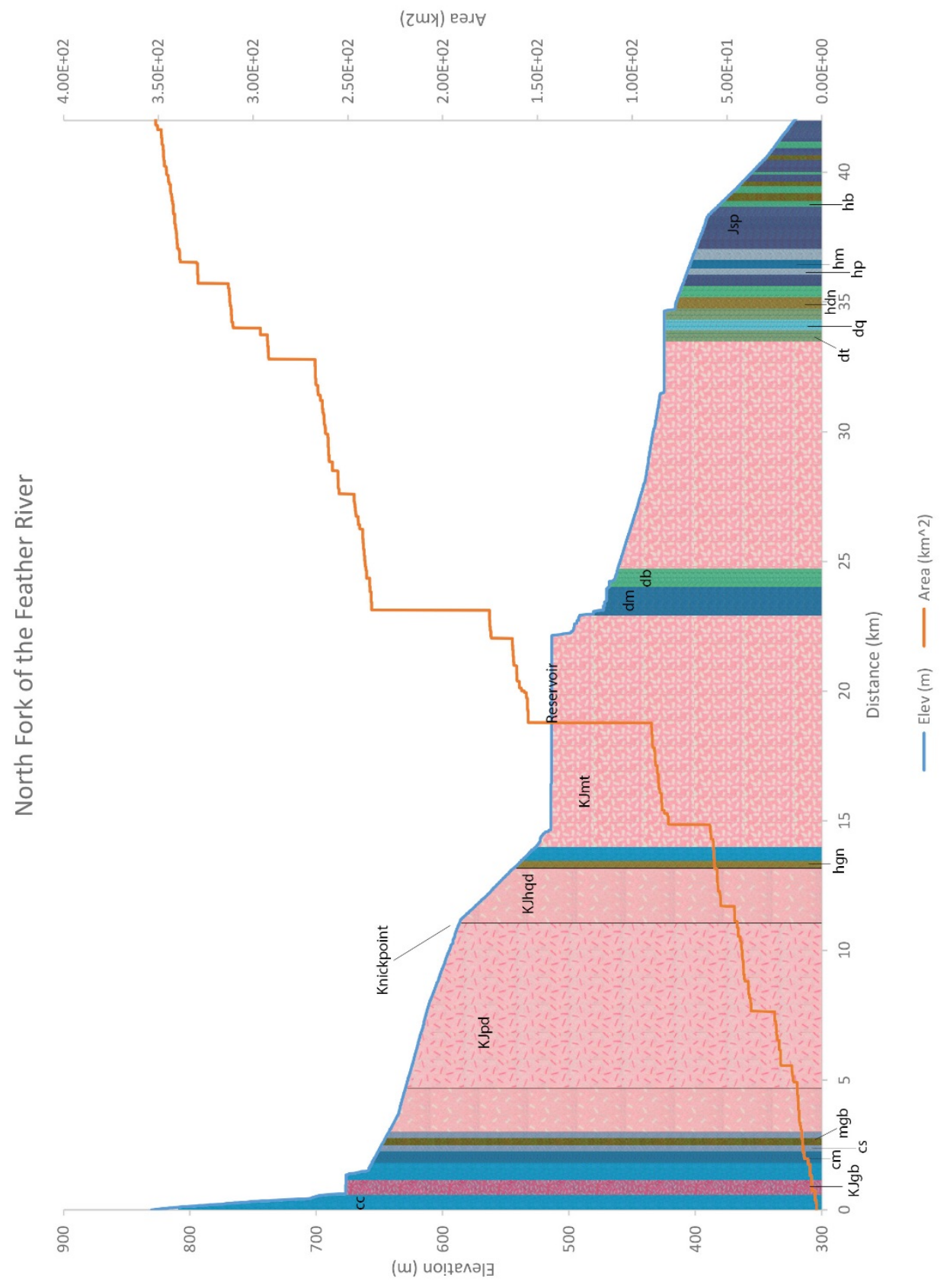


APPENDIX 2-G. North Fork Feather River: Legend

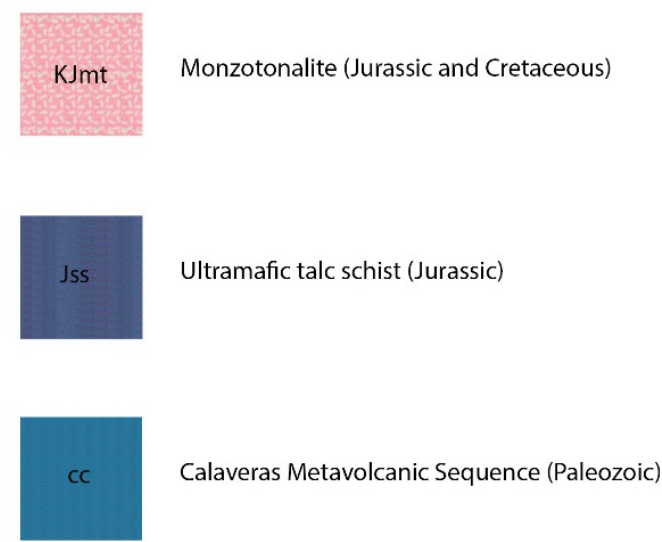

$\mathrm{db}$

Duffy Dome Metavolcanic Sequence (Paleozoic) 